\title{
Engagement with protective behaviours in the UK during the COVID-19 pandemic: A series of cross-sectional surveys (the COVID-19 Rapid Survey of Adherence to Interventions and Responses [CORSAIR] study)
}

Louise E Smith (0000-0002-1277-2564), ${ }^{1,2}$ PhD, Henry WW Potts (0000-0002-6200-8804), ${ }^{3}$ PhD, Richard Amlôt, ${ }^{2,4} \mathrm{PhD}$, Nicola T Fear (0000-0002-5792-2925), ${ }^{1,5}$ DPhil (Oxon), Susan Michie (0000-0003-0063-6378), ${ }^{6}$ DPhil, G James Rubin,,${ }^{1,2} \mathrm{PhD}$

1 King's College London, Institute of Psychiatry, Psychology and Neuroscience

2 NIHR Health Protection Research Unit in Emergency Preparedness and Response

3 University College London, Institute of Health Informatics

4 UK Health Security Agency, Behavioural Science Team, Emergency Response Department Science and Technology

5 King's Centre for Military Health Research and the Academic Department of Military Mental Health, King's College London

6 University College London, Centre for Behaviour Change

Corresponding author: Louise E Smith, Post-doctoral Researcher. Department of Psychological Medicine, King's College London, Weston Education Centre, Cutcombe Road, London, SE5 9RJ. Email: louise.e.smith@kcl.ac.uk

Henry WW Potts, Professor of Health Informatics. Institute of Health Informatics, 222 Euston Road, London, NW1 2DA.

Richard Amlôt, Head of Behavioural Science in the Behavioural Science and Insights Unit at UK Health Security Agency. Porton Down, Salisbury, Wiltshire, SP4 0JG. 
Nicola T Fear, Professor of Epidemiology. Department of Psychological Medicine, King's College London, Weston Education Centre, Cutcombe Road, London, SE5 9RJ.

Susan Michie, Professor of Health Psychology. Centre for Behaviour Change, University College London, 1-19 Torrington Place, London, WC1E 7HB.

G James Rubin, Assistant Director. NIHR Health Protection Research Unit in Emergency Preparedness and Response, King's College London, Weston Education Centre, Cutcombe Road, London, SE5 9RJ. 


\begin{abstract}
Background: Behaviour is key to suppressing the COVID-19 pandemic. Maintaining behaviour change can be difficult. We investigated engagement with hand cleaning, reducing the number of outings, and wearing a face covering over the course of the pandemic.

Methods: We used a series of 64 cross-sectional surveys between 10 February 2020 and 20 January 2022 ( $n \approx 2,000$ per wave). Surveys investigated uptake of hand cleaning behaviours, out of home activity (England only, $\mathrm{n} \approx 1,700$ per wave) and wearing a face covering (England only, restricted to those who reported going out shopping in the last week, $n \approx 1,400$ per wave).
\end{abstract}

Results: Reported hand cleaning has been high throughout the pandemic period (85\% to 90\% of participants consistently reporting washing their hands thoroughly and regularly with soap and water frequently or very frequently). Out of home activity has mirrored the easing and reintroduction of restrictive measures. Total number of outings were higher in the second national lockdown. Wearing a face covering increased steadily between April to August 2020, plateauing until the end of measurement in May 2021, with approximately $80 \%$ of those who had been out shopping in the previous week reporting wearing a face covering frequently or very frequently.

Conclusions: Engagement with protective behaviours increased at the start of the pandemic and has remained high since. The greatest variations in behaviour reflected changes to Government rules. Despite the duration of restrictions, people have continued to adopt personal protective behaviours that were intended to prevent the spread of COVID-19.

Key words: uptake, face covering, hand hygiene, hand cleaning, social distancing, physical distancing, behavioural fatigue

Abstract word count: $243 / 350$ 


\section{Background}

The COVID-19 pandemic brought with it a new way of life, with a sudden emphasis on behaviours to help prevent the spread of illness, including hand cleaning, reducing contact with others, and wearing a face covering. In the absence of pharmacological interventions, populations around the globe relied on these changes to behaviour to reduce the transmission of COVID-19.(1) Recommendations to adopt protective behaviours have come at different points during the pandemic. For example, in the UK, the public were urged to adopt respiratory and hand hygiene behaviours by a public information campaign launched on 2 February 2020,(2) to limit their social contact with others on 16 March 2020(3) and to enter the first lockdown on 23 March 2020.(4) Since this date, a complex series of changes in restrictions has taken place. Rules on wearing a face covering were introduced later. Dates of introduction differed by nation, ${ }^{1}$ but it became mandatory in England on public transport on 15 June 2020,(5) in shops on 24 July,(6) and in restaurants on 24 September.(7) Exceptions were made for young children and people with certain medical conditions. All rules on social contact and wearing a face covering were removed on 19 July 2021.(8) However, the emergence of the Omicron variant of concern brought with it the reimposition of rules on wearing a face covering and working from home.(9-11)

Most studies conducted during the pandemic have focused on identifying adherence to certain protective behaviours and identifying factors associated with adherence. Fewer have investigated behaviour over time, likely as these are more time consuming and costly to conduct. One study, conducted between April 2020 and February 2021, indicated that selfreported compliance with Government guidelines decreased in approximately $15 \%$ of participants.(12) Market research surveys indicate that levels of wearing a face covering increased between May and September 2020, after which they remained at a steady high rate(13) until the removal of the mandate as part of the 19 July 2021 changes, after which rates of wearing a face covering dropped.(14)

Understanding how engagement with protective behaviours varies over time informs actions that may need to be taken to support maintenance of these behaviours long-term. There is also a need to understand whether there is a difference in rate of adoption between a familiar

\footnotetext{
${ }^{1}$ Mandatory use of face coverings differed by nation. England: 15 June 2020 - public transport; 24 July 2020 shops; 24 September 2020 - restaurant workers and in restaurants. Scotland: 22 June 2020 - public transport; 10 July 2020 - shops; 14 August 2020 - indoor public spaces including restaurants. Wales: 27 July 2020 - public transport; 14 September 2020 - indoor public spaces including shops and restaurants. Northern Ireland: 10 July 2020 - public transport; 10 August 2020 - shops; 14 October 2020 - restaurants.
} 
behaviour such as hand cleaning and a novel (for the UK) behaviour such as wearing a face covering. Previous international research has noted that mandating the wearing of protective equipment (such as bicycle helmets) does not necessarily lead to an immediate widespread uptake.(15-17) Research suggests that behaviours may become habitual in around one to three months.(18)

In this study, we investigated trends in uptake of protective behaviours during the COVID-19 pandemic in the UK. We used a series of 64 cross-sectional surveys to investigate uptake of three recommended protective behaviours which may influence transmission of COVID-19 over the course of the pandemic. These were: a) hand cleaning (a behaviour recommended before the pandemic that many people are nonetheless poor at performing (19)); b) leaving the home less frequently; and c) wearing a face covering (a novel behaviour for most people in the UK).

\section{Methods}

\section{$\underline{\text { Design }}$}

Since 28 January 2020, before the first UK cases of COVID-19 were reported, a series of cross-sectional surveys has been conducted by BMG Research and then Savanta on behalf of the Department of Health and Social Care, England. Surveys were initially weekly, then usually fortnightly from mid-July 2020. The methods for these surveys have been described in detail elsewhere.(20) In this study, we used data from 10 February 2020 (wave 3) to 20 January 2022 (wave 66).

\section{$\underline{\text { Participants }}$}

Approximately 2,000 participants (people aged 16 years or over living in the UK) completed each survey wave $(\approx 1,700$ from England per wave). Quota sampling was used, with quotas applied based on age and gender (interlocked) reflecting targets from Office for National Statistics data.(21) From wave 8 of the survey onwards, two specialist research panel providers were used to recruit participants: Respondi $(n=50,000)$ and Savanta $(n=31,500)$. Before then, participants were recruited solely from the Respondi panel. Participants could complete multiple survey waves, but after having completed the survey once were excluded from the subsequent three waves. An error with one of the survey panels meant this exclusion rule was not applied in the first waves of data collection, leading to a small number of people (at least $n=133,0.2 \%$ of sample) completing the survey nine times or more up to 18 
November 2020 (wave 30). We have adjusted statistically for participants appearing in multiple waves, where possible. Due to an error, some repeat participants were not identified in the data available. We were unable to identify repeat participants from one of the panels before 20 September 2021 (wave 58). The impact of adjusting for repeat participants on the results is minimal. Therefore, this inability to identify some repeat participants should not have any material impact on results. Participants were reimbursed for having completed the survey in points, which could be redeemed as cash, gift vouchers or charitable donations (up to $70 \mathrm{p}$ per survey).

\section{$\underline{\text { Measures }}$}

Full survey items are reported in the supplementary materials.

Hand cleaning: From 10 January 2020 (wave 3), participants were asked if they had washed their hands thoroughly and regularly with soap and water in the past seven days. Response options were "done this, same amount as usual," "done this, more than usual," "not done this," and "not applicable." Between 27 April 2020 (wave 14) to 13 May 2020 (wave 16), the sample was split, with half the sample being asked to respond using the original options, and half the sample being asked to respond on a five-point scale from "never" to "very frequently." From 18 May 2020 (wave 17) onwards, all participants responded on the fivepoint scale. From 26 October 2020 (wave 31) onwards, the item was amended so that participants were asked if they had "washed [their] hands thoroughly and regularly with soap and water, or used hand sanitising gel". We created binary variables to indicate if people reported washing their hands frequently or very frequently (compared to never, rarely or occasionally). This item was removed from the survey after 19 May 2021 (wave 50). For these variables, "not applicable" was coded as missing $(n=847,0.9 \%)$.

Number of outings: Participants were asked to state the number of times they had been out of their home in the last seven days to go: to the shops, for groceries/pharmacy; to the shops, for things other than groceries/pharmacy; for a walk or some other exercise; to spend time outdoors for recreational purposes; out to work; to meet up with friends and/or family they did not live with; and to a restaurant, café or pub. These questions were introduced to the surveys on 30 March 2020 (wave 10), with the exception of spending time outdoors for recreational purposes, which was introduced on 18 May 2020 (wave 17), and going out to a restaurant, café or pub, which was introduced on 6 July 2020 (wave 24). This question was amended on 1 June 2021 (wave 51), and from this date on, asked participants to state the 
number of times they had done each of the following activities in the past seven days, including having: been to the shops, for groceries/pharmacy; been to the shops, for things other than groceries/pharmacy; spent time outdoors for exercise or recreational purposes (including to sit in parks etc.); left the house to go out to work (number of days); met up with friends and/or family that you don't live with; and been to a restaurant, café or pub. To investigate total number of outings where people were likely to come into close contact with someone from another household indoors, we created three separate variables. The first variable summed outings for shopping and to see friends or family from another household to give a "total number of outings" variable. As the item investigating outings to hospitality venues was introduced later, we created a second variable that also included going out to a restaurant, café or pub. A third variable, summing outings for shopping, to see friends or family from another household, visiting hospitality venues and for work was also created, but only calculated for those who reported being in employment.

Wearing a face covering: Participants were asked if they had worn a professional face mask or a homemade, cloth or improvised face covering (such as a scarf) when out and about in the last seven days on a five-point scale from "never" to "very frequently." Between 27 April 2020 (wave 14) to 13 May 2020 (wave 16), this question was only asked to half the sample. From 18 May 2020 (wave 17), all participants were asked to respond on the five-point scale. We coded participants as wearing a face covering if they selected "very frequently" or "frequently" for either or both of the face covering items. On 26 October 2020 (wave 31), the two items were replaced by a single item asking how frequently participants had "worn a face mask or another face covering (such as a scarf) when out and about". This item was removed from the survey after 19 May 2021 (wave 50). For these items, we treated answers of "not applicable" as not having worn a face covering frequently or very frequently $(n=432,0.8 \%)$.

\section{Participant characteristics}

Participants were asked to report their sex, age, ethnicity, highest level of educational or professional attainment, ethnicity, employment status and socio-economic grade.(22) Region was derived from participants' postcodes.

\section{$\underline{\text { Ethics }}$}

This work was conducted as part of a service evaluation of the marketing and communications run by the Department of Health and Social Care, and so did not require 
ethical approval. We sought advice from the Psychiatry, Nursing and Midwifery Research Ethics Office, King's College London and they confirmed this position.

\section{$\underline{\text { Analysis }}$}

For analyses investigating hand cleaning, we used data from all participants completing the survey between 10 February 2020 and 19 May 2021 (wave 3 to 50), as these were the dates that the relevant outcome question was included ( $\mathrm{n}=95,998$ responses).

Due to differences in rules on outings in the devolved nations, we restricted the sample to include only participants living in England (included in surveys between 30 March 2020 and 20 January 2022 [waves 10 to 66], $n=100,736$ responses). For the number of outings for work, we restricted analyses to those who reported they were in full-time, part-time or selfemployment ( $\mathrm{n}=54,504$ responses).

For analyses of wearing a face covering, due to differences in rules in the devolved nations, we restricted the sample only to those in England who reported having been out shopping in the last seven days (included in survey between 27 April 2020 and 19 May 2021 [waves 14 to $50], \mathrm{n}=52,285$ responses).

We described the engagement with protective behaviours descriptively and graphically, using line graphs to show the percentage of people who reported engaging in hand cleaning frequently or very frequently, the number of times people reported going out in the last week for various reasons, and the percentage of people who reported wearing a face covering frequently or very frequently. For each data point, we calculated $95 \%$ confidence intervals.

For analyses investigating hand washing and wearing a face covering, phrasing of the question changed on 26 October 2020 (wave 31). We compared data from 28 September to 11 November 2020 (waves 29 to 32; last two waves of the original compared to first two waves of the updated question wording; no repeat respondents) using a $\chi^{2}$-test, to investigate whether responses for the different question wordings were comparable.

We used generalised estimating equations (GEEs) to investigate whether engagement with protective behaviours differed by survey wave, accounting for repeat respondents where possible. For binary outcomes (hand washing, wearing a face covering), we used logistic regression analyses, reporting odds ratios (ORs). For count data (total outings), we used negative binomial regressions, reporting incidence rate ratios (IRRs). We also investigated whether total outings differed between lockdown periods. As participants reported on their 
behaviour in the previous seven days, we selected waves where the reporting period was solely contained under lockdown restrictions (first lockdown: 30 March to 6 May 2020, waves 10 to 15; second lockdown: 16 November to 2 December 2020, waves 33 to 35; third lockdown: 25 January to 24 February 2021, waves 42 to 44 ).

\section{Results}

\section{$\underline{\text { Respondent characteristics }}$}

Respondent characteristics are reported in Table 1. Approximately half of responses were from women (53\%), with a mean age of 48.5 years. Respondents' ethnicity was broadly reflective of the general population.(23)

Table 1. Respondent characteristics

\begin{tabular}{|c|c|c|c|}
\hline Respondent characteristics & Level & $\mathrm{N}$ & Percentage $(\%)$ \\
\hline \multirow[t]{2}{*}{ Sex } & Male & 61,470 & 46.6 \\
\hline & Female & 70,574 & 53.4 \\
\hline Age (years) & Range $=16$ to over 100 & \multicolumn{2}{|c|}{$\begin{array}{l}\text { Mean }=48.5, \text { standard } \\
\text { deviation }=17.8\end{array}$} \\
\hline \multirow[t]{4}{*}{ Nation } & England & 112,882 & 85.2 \\
\hline & Scotland & 10,457 & 7.9 \\
\hline & Wales & 6,672 & 5.0 \\
\hline & Northern Ireland & 2,449 & 1.8 \\
\hline \multirow[t]{7}{*}{ Ethnicity } & White British & 111,275 & 84.0 \\
\hline & White other & 8,241 & 6.2 \\
\hline & Mixed & 2,929 & 2.2 \\
\hline & Asian / Asian British & 6,114 & 4.6 \\
\hline & Black / Black British & 2,610 & 2.0 \\
\hline & Arab / other & 539 & 0.4 \\
\hline & Prefer not to say & 752 & 0.6 \\
\hline \multirow[t]{2}{*}{ Employment status } & Not working & 59,631 & 45.6 \\
\hline & Working & 71,191 & 54.4 \\
\hline \multirow[t]{3}{*}{ Socio-economic grade } & $\mathrm{AB}$ & 38,325 & 29.6 \\
\hline & $\mathrm{C} 1 \mathrm{C} 2$ & 54,115 & 41.7 \\
\hline & DE & 37,205 & 28.7 \\
\hline \multirow[t]{2}{*}{$\begin{array}{l}\text { Highest educational or } \\
\text { professional qualification }\end{array}$} & $\begin{array}{l}\text { GCSE/vocational/A-level/No } \\
\text { formal qualifications }\end{array}$ & 87,814 & 66.3 \\
\hline & $\begin{array}{l}\text { Degree or higher (Bachelors, } \\
\text { Masters, } \mathrm{PhD} \text { ) }\end{array}$ & 44,646 & 33.7 \\
\hline
\end{tabular}

\section{Hand cleaning}

The percentage of people who reported washing their hands thoroughly and regularly more than usual increased sharply between February and April 2020 from 22\% to approximately 
$70 \%$ (Figure $1 ; \chi^{2}(12)=2725.8, p<.001$; supplementary materials). The percentage of people reporting washing their hands thoroughly and regularly frequently or very frequently remained relatively stable at 90\% from May 2020, with small decreases seen in April and May 2021. Although this change was statistically significant $\left(\chi^{2}(36)=117.2, p<.001\right.$; supplementary materials), in practice, there was only a small change in the percentage of people engaging in thorough hand washing (approximately $90 \%$ to $85 \%$ ). 
Figure 1. Graph depicting the percentage of people who reported washing their hands thoroughly and regularly, between February 2020 and May 2021. Dashed lines indicate those who reported hand cleaning more than usual; solid lines indicate those who reported hand cleaning frequently or very frequently. Error bars are $95 \%$ confidence intervals.

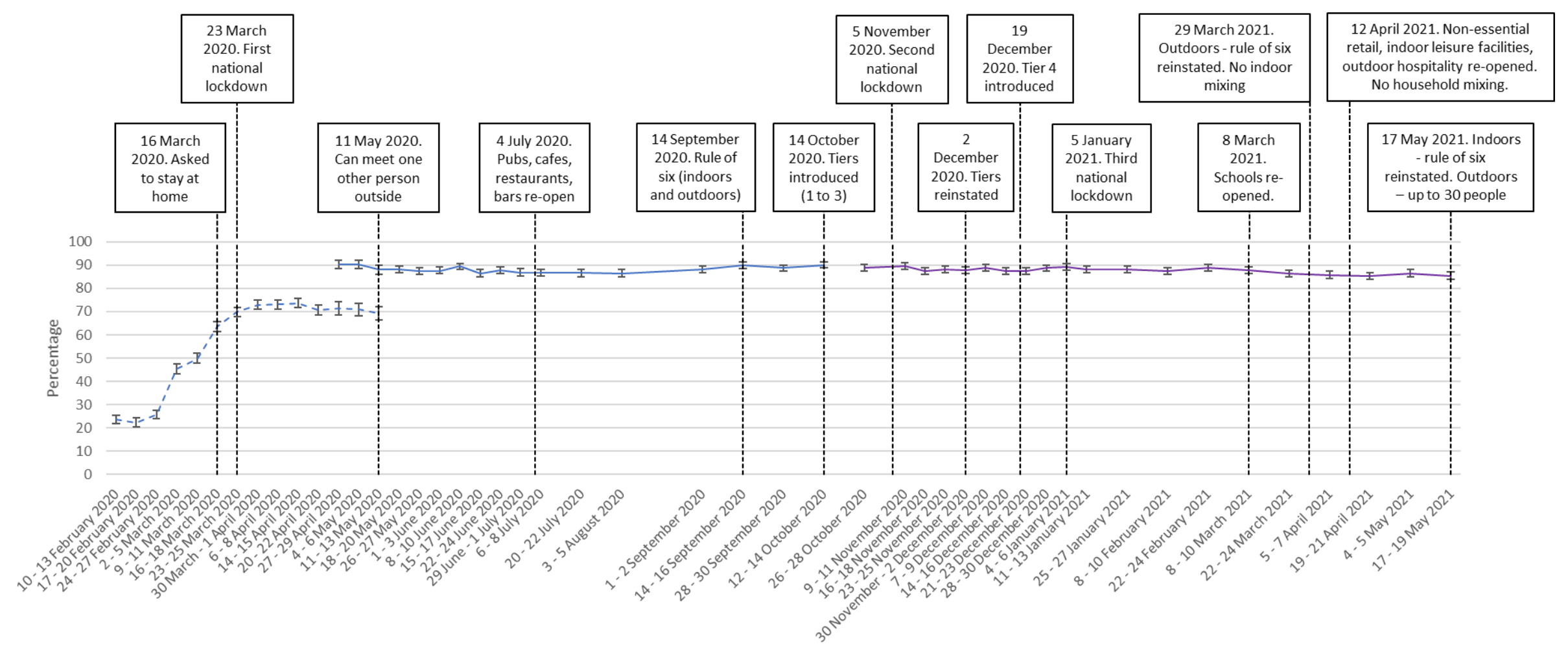

Date 
Changing the question wording made no difference to results $\left(\chi^{2}(3)=2.5, p=0.48\right)$.

\section{Number of outings}

During the initial period of restrictions, outings to meet up with friends or go to shops for non-essential goods (both prohibited activities) were low (see Figure 2). These increased, roughly in line with visits to restaurants, cafes and pubs when the item was introduced, until September 2020, when new restrictions on the maximum number of people able to meet and a new work from home recommendation were issued. During the second (November 2020) and third (January 2021 to March 2021) national lockdowns, these rates fell but remained higher than during the first lockdown. Leaving home to go to the shops for groceries or pharmacy goods has shown a similar general pattern, albeit at higher overall levels. 
Figure 2. Graph depicting the mean number of times that people reported going out for different reasons in the last seven days, between March 2020 and January 2022. Error bars are 95\% confidence intervals.

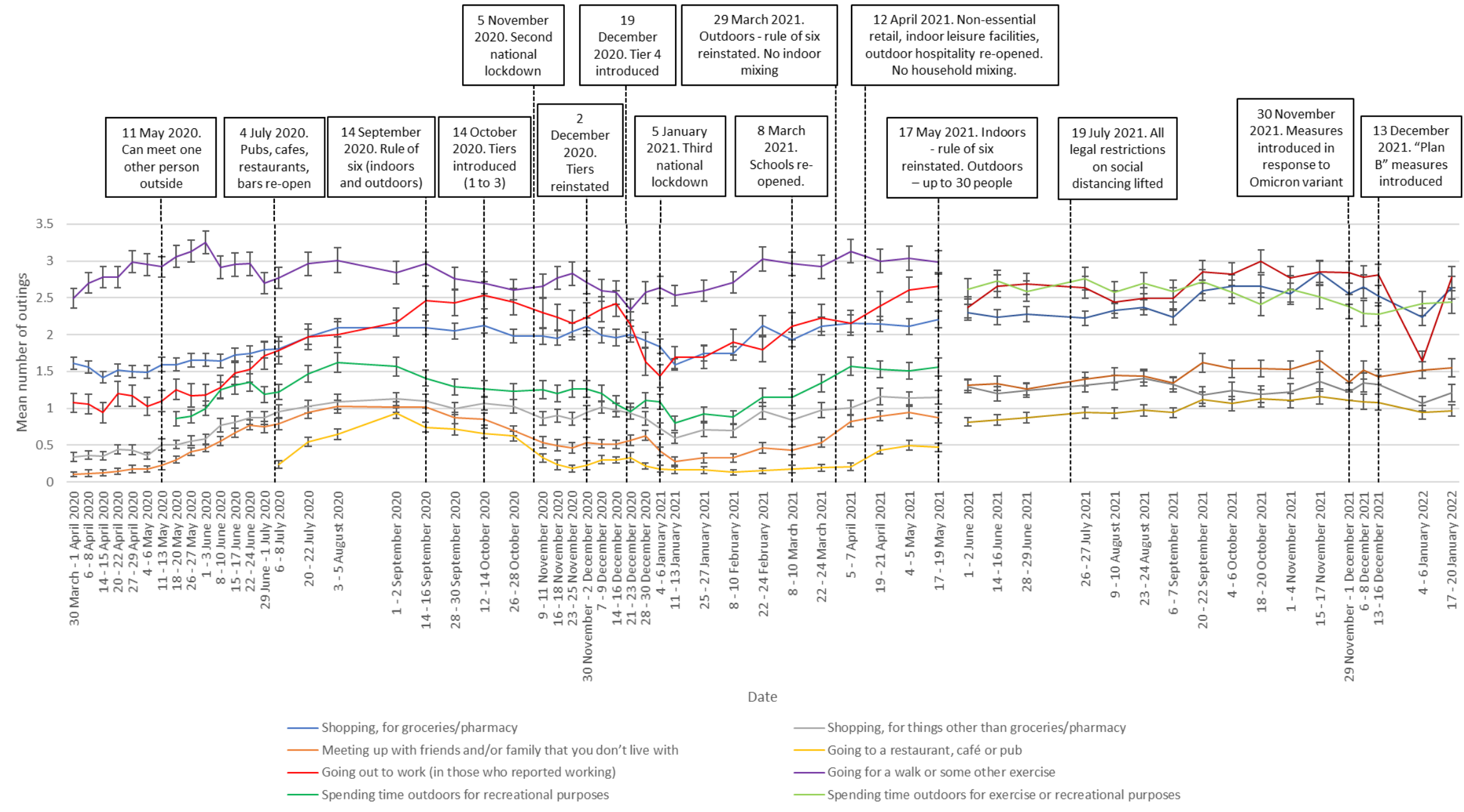


Leaving home to go to work was initially at very low levels during the first lockdown, despite being allowed where necessary. This showed an increase over time from May 2020 until September 2020, when a request to work from home where possible was once again introduced. There was no change between September to October 2020, after which point it decreased during the second lockdown (November 2020). Levels of going out to work increased over the third lockdown (January 2021 to June 2021), then stabilising at the highest rate in the pandemic in September to December 2021. Levels of going out to work over the festive period fell sharply, but returned back to similar levels in January 2022.

The most common reason for leaving home throughout the pandemic was to go for a walk or some other exercise. This showed an initial increase from March to June 2020, then a slight decrease in early June and again since late September 2020. Levels of spending time outdoors for recreational purposes was lower, but showed increases during times with fewer restrictions. From June 2021, number of times spent outdoors for exercise or recreational purposes has consistently been among the most common reasons for leaving home.

Total number of outings increased steadily from March to September 2020, after which it fell (see Figure 3). Total outings during the second (November 2020) and third (January to March 2021) national lockdowns were higher than during the first lockdown in (March to May 2020; $\chi^{2}(2)=574.4, p<.001$; supplementary materials). Outings during the third lockdown were lower than those seen in the second lockdown (IRRs 0.86-0.87 (95\% CIs 0.81-0.82 to 0.910.92), $p s<.001$; supplementary materials). After that, rates steadily climbed, until January 2021 after "Plan B" measures were introduced.(10) 
Figure 3. Graph depicting the total number of outings in the last seven days, between March 2020 and January 2022. Error bars are 95\% confidence intervals.

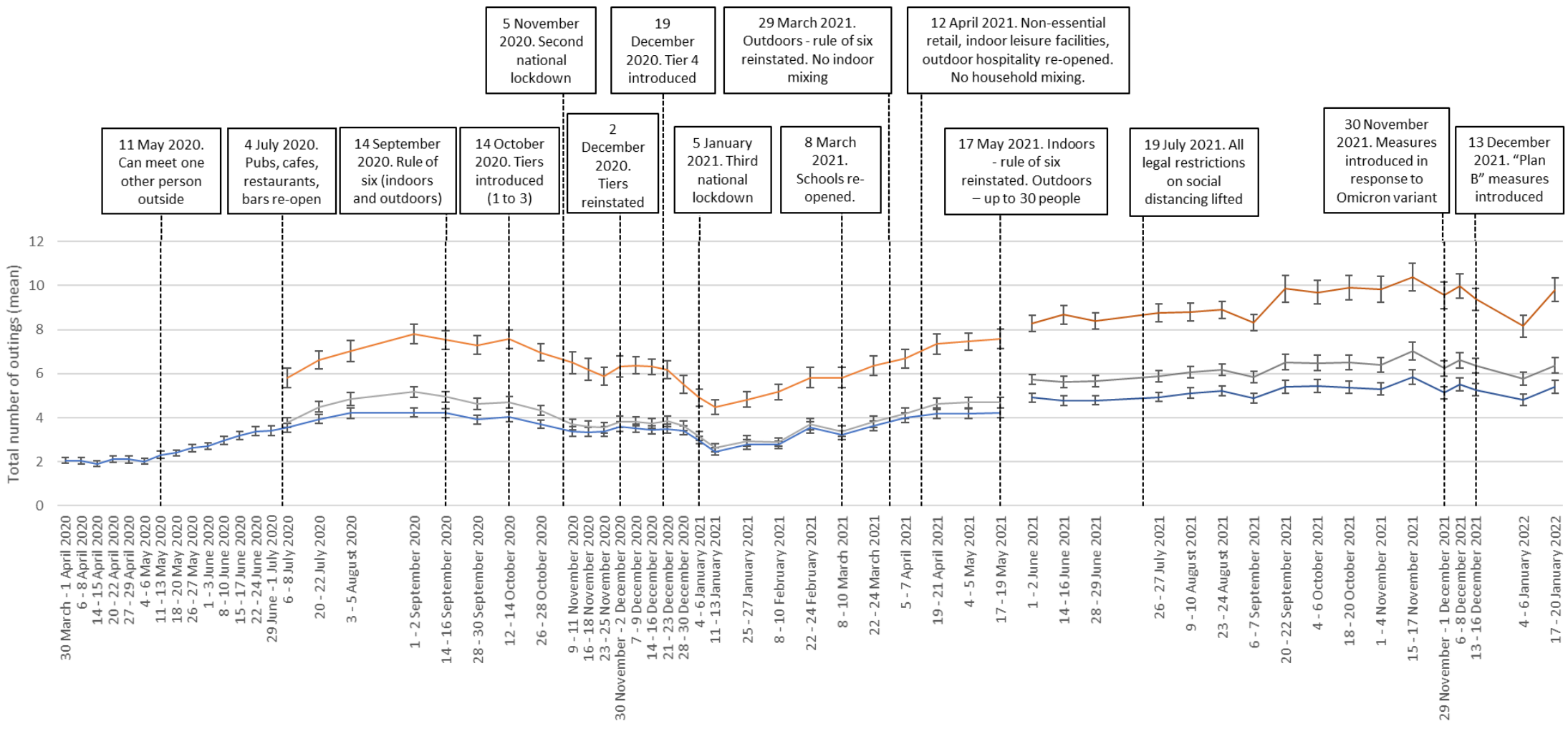

Eor shopping and to see people from another household

_ For shopping, to see people from another household, and to go to a restaurant/café/pub

- For shopping to see people from another household, to go to a restaurant/café/pub, and go out to work (in those who reported working) 


\section{Wearing a face covering}

The percentage of people reporting wearing a face covering frequently or very frequently differed significantly between April 2020 and May $2021\left(\chi^{2}(36)=8118.2, p<0.001\right.$; supplementary materials). Rates of wearing a face covering were stable from late April to mid-May 2020, when guidance on face coverings was produced (see Figure 4; ORs 0.98-1.07 (95\% CIs $0.79-0.87$ to $1.22-1.32$, $p s=0.52-0.88$; supplementary materials). This was followed by a sudden, small increase. Following a plateau, discussion and then a series of laws making coverings mandatory in different locations there was a steady increase between early June and August. Wearing of face coverings stabilised at around 80\% between September 2020 to March 2021, after which they decreased slightly $\left(\chi^{2}(19)=82.3, p<.001\right)$. Despite a statistically significant difference, in practice rates only fell by approximately $4 \%$ (approximately $82 \%$ to $78 \%)$ 
Figure 4. Graph depicting the percentage of people who reported wearing a face covering frequently or very frequently when out and about in the last seven days in those who reported having been shopping, between April 2020 and May 2021. Error bars are 95\% confidence intervals.

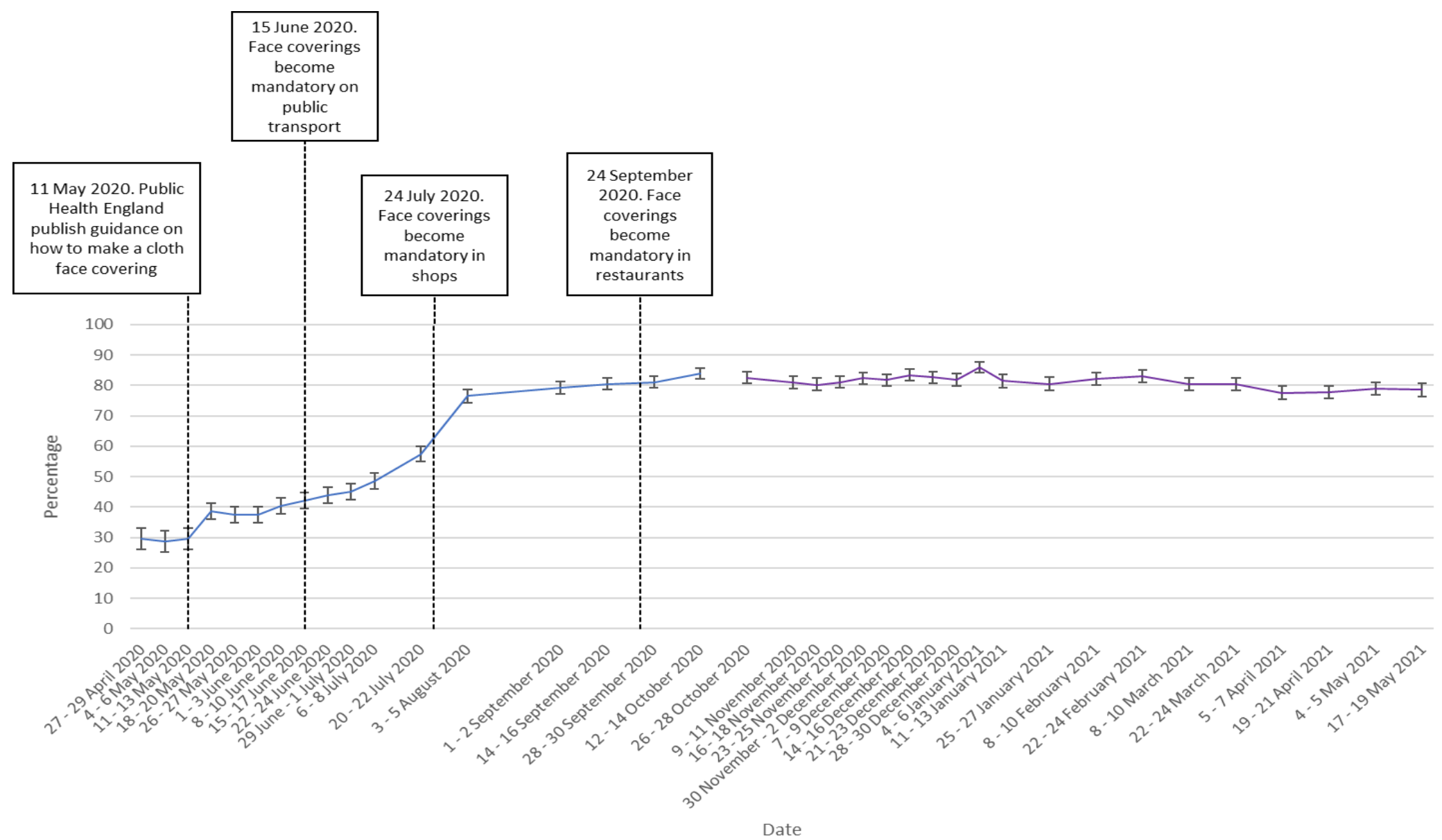

Worn a professional face mask when out and about, or worn a homemade, cloth or improvised face covering (such as a scarf) when out and about

Worn a face mask or another face covering (such as a scarf) when out and about 
Changing the question wording made no difference to results $\left(\chi^{2}(3)=5.8, p=0.12\right)$.

\section{Discussion}

Key recommended behaviours increased at the start of the COVID-19 pandemic and have been maintained at high levels as the pandemic has progressed. Self-reported hand cleaning showed a marked increase in the first few weeks of the pandemic and remained at high levels thereafter. Despite a statistically significant decrease in rates of frequent handwashing between April and May 2021, rates of frequent hand washing only changed by a small amount (approximately 85\% frequent hand washing compared to 90\%). In a separate survey, rates of people "improving personal hygiene" also increased steeply between March and May 2020, then fell steadily until January 2022.(13) This difference in results may be explained in part by the phrasing of the survey item, with people no longer "improving" their personal hygiene measures, but maintaining them at a high level, as suggested by our results. Due to the use of self-report measures, it is likely that rates are over-estimates of engagement with protective behaviours.

The number of outings reported reflects a more complex picture but broadly mirrors UK Government guidance, rising as restrictions were eased over the summer of 2020, falling as they were re-introduced in September (rule-of-six), October (tiers), and November (second lockdown) 2020, decreasing further with the start of the third national lockdown in January 2021, and then rising steadily with the removal of all restrictions on social mixing in summer 2021. Objective measures corroborate these findings, with evidence from mobile phone location data indicating that people's out of home activities have changed in line with national restrictions.(24-26) Other data from our group also suggest that the biggest influence in patterns of social mixing is guidance in place at the time.(27) The one notable exception is leaving home to go to work. In both the UK's March lockdown and England's November lockdown, people were asked to work from home, but to go to work if that was not possible. $(28,29)$ However, the impact on work from home was weaker in November and self-reported rates of going out to work were higher in November than in March. We also saw a sharp drop in the percentage of people reporting having been out to work at the start of January 2022. Rather than reflecting changes in guidance ("Plan B"), this is likely due to the closure of many workplaces over the festive period, as demonstrated by returns to higher levels in January 2022. Our findings present an insight into complex behaviour changes in routine out-of-home activities over the course of the pandemic. 
The total number of outings during the second (November 2020) and third (January to February 2021) English lockdowns were higher than during the first lockdown (March to May 2020. The second lockdown was less strict than the first lockdown, with outings to meet an individual socially outside being allowed, and schools, universities and more workplaces remaining open. $(28,29)$

For wearing a face covering, a behaviour that was not commonplace in the UK before the pandemic, uptake increased slowly at the start of the pandemic until September 2020 and subsequently remained at a stable high level, followed by a slight decrease in April to May 2021. This is in line with other data collected between March 2020 and January 2021.(30) Data collected after the period of data collection for this study shows that the percentage of people wearing a face covering in shops decreased after the mandate was lifted, and then increased after the mandate was reintroduced in response to the emergence of the Omicron variant of concern. $(11,13,14)$

Rates of hand cleaning increased sharply at the beginning of the pandemic, while rates of wearing face coverings increased slowly. This could have been due to lack of social norms and low perceived effectiveness of wearing face coverings. These factors are theoretically associated with uptake of health behaviours (e.g. as part of reflective motivation in the COMB model, Theory of Planned Behaviour (31)). At the start of the pandemic, reflective motivation was strongly associated with adopting good hygiene practices.(32) Greater perceived effectiveness and social norms have been shown to be associated with uptake of protective behaviours during the COVID-19 pandemic,(33) including wearing a face covering.(34-36)

The term "behavioural fatigue" has come to be used colloquially as a slightly amorphous 'catch-all' term for an inevitable decline adherence to protective behaviours.(37) Despite its common use in the media and implication in previous policy decisions (e.g. (38)), there is little evidence to support this notion. In our data, uptake of behaviours tended to increase and was then maintained over a long period of time. Other studies have also found this pattern of behaviour.(13, 30, 36, 39) Where studies have found decreases in engagement with protective behaviours, this has only been in a small percentage of people.(12)

The causes of changes in engagement with protective behaviours over time are unclear.(40) The COM-B model suggests that decreases in engagement with protective behaviours are the result of decreasing capability, opportunity and/or motivation.(31) While motivation to 
engage with certain protective behaviours may have decreased, capability and opportunity have likely grown over the course of the pandemic. For example, we now know more about COVID-19 transmission than at the start of the pandemic (psychological capability). Physical opportunity may also have increased, with many indoor shared spaces making hand sanitiser freely available and configuring their settings to allow physical distancing. Wearing a face covering, previously not a common behaviour in the UK, has now become commonplace, increasing social norms (social opportunity). Over the course of the pandemic, there has been ample time for protective behaviours to become routine or even habitual, a process which takes weeks or months.(18)

Strengths of this study include the use of a large sample to investigate trends in engagement with protective behaviours over the entire pandemic. The measurement of multiple out-ofhome activities gives insight into how complex routine behaviours have changed. This study has some limitations. Participants were recruited into the study using quota sampling to ensure that the sample was broadly representative of the UK population, based on Office for National Statistics data.(21) Respondents were slightly more likely to be women than in the general population. We cannot be sure that the views of survey respondents are representative of the general population. $(41,42)$ Data were self-reported and may be influenced by social desirability and recall biases. The phrasing of some of the questions may encourage positive reporting. In another study, people were less likely to report washing their hands if the question was framed negatively compared to positively.(43) The phrasing of some items changed over the course of the surveys, making direct comparisons difficult. Some items introduced a degree of subjectivity (e.g. washing hands "thoroughly and regularly"). Survey questions may be unable to detect subtle changes in behaviour, for example, the duration of hand washing, that may still have implications for viral transmission.

\section{Conclusions}

While self-reported rates of hand cleaning, out of home activity and wearing a face covering should be taken with caution, trends in the data paint a useful picture of engagement with protective behaviours among the UK population over a long period of time. Our results indicate that hand cleaning increased rapidly at the start of the pandemic and remained high since. Adoption of a previously uncommon behaviour in the UK, wearing a face covering, increased more slowly, but has remained at a stable high rate while a mandate was in operation. Out of home activity reflected UK Government guidance in place at the time. 
Results have important implications for policy makers, indicating that engagement with protective behaviours can be maintained over a long period of time, and that behaviour largely follows rules in place.

\section{Abbreviations}

$\mathrm{UK}=$ United Kingdom 


\section{Declarations}

\section{Ethics approval and consent to participate}

This work was conducted as part of a service evaluation of the marketing and communications run by the Department of Health and Social Care, and so did not require ethical approval. We sought advice from the Psychiatry, Nursing and Midwifery Research Ethics Office, King's College London and they confirmed this position. Participants of online research panels have consented to being contacted to take part in online surveys. Following industry standards, consent was implied by participants' completion of the survey.

\section{Consent for publication}

Not applicable.

\section{$\underline{\text { Availability of data and materials }}$}

The data that support the findings of this study are available from the Department of Health and Social Care but restrictions apply to the availability of these data, which were used under license for the current study, and so are not publicly available. Data are however available from the authors upon reasonable request and with permission of the Department of Health and Social Care.

\section{Competing interests}

All authors had financial support from NIHR for the submitted work; RA is an employee of the UK Health Security Agency; HWWP has received additional salary support from Public Health England and NHS England; HWWP receives consultancy fees to his employer from Ipsos MORI and has a PhD student who works at and has fees paid by AstraZeneca; NTF is a participant of an independent group advising NHS Digital on the release of patient data. All authors are members of the UK's Scientific Advisory Group for Emergencies or its subgroups. There are no other financial relationships with any organisations that might have an interest in the submitted work in the previous three years and no other relationships or activities that could appear to have influenced the submitted work.

\section{Funding}

This work was funded by the National Institute for Health Research (NIHR) Health Services and Delivery Research programme. Surveys were commissioned and funded by Department of Health and Social Care (DHSC), with the authors providing advice on the question design 
and selection. LS, RA and GJR are supported by the National Institute for Health Research Health Protection Research Unit (NIHR HPRU) in Emergency Preparedness and Response, a partnership between the UK Health Security Agency, King's College London and the University of East Anglia. RA is also supported by the NIHR HPRU in Behavioural Science and Evaluation, a partnership between the UK Health Security Agency and the University of Bristol. HP has received funding from Public Health England and NHS England. NTF is part funded by a grant from the UK Ministry of Defence. Surveys were commissioned and funded by Department of Health and Social Care (DHSC), with the authors providing advice on the question design and selection. DHSC saw drafts of this paper and were offered the chance to comment. DHSC had no role in the decision to publish. The authors retained full control over the paper's content. Preliminary results were made available to DHSC and the UK's Scientific Advisory Group for Emergencies. The views expressed are those of the authors and not necessarily those of the NIHR, UK Health Security Agency, the Department of Health and Social Care or the UK Ministry of Defence.

\section{$\underline{\text { Authors' contributions }}$}

All authors conceptualised the study and contributed to survey materials. LS completed analyses with guidance from HWWP and GJR. LS wrote the first draft of the manuscript. LS, HWWP, RA, NTF, SM and GJR contributed to, and approved, the final manuscript. The corresponding author attests that all listed authors meet authorship criteria and that no others meeting the criteria have been omitted.

\section{$\underline{\text { Acknowledgements }}$}

Not applicable 


\section{References}

1. West R, Michie S, Rubin GJ, Amlot R. Applying principles of behaviour change to reduce SARS-CoV-2 transmission. Nat Hum Behav. 2020;4(5):451-9.

2. Department of Health and Social Care. Coronavirus public information campaign launched across the UK. 3 February 2020. Available from:

https://www.gov.uk/government/news/coronavirus-public-information-campaign-launchedacross-the-uk.

3. Boris Johnson. Prime Minister's statement on coronavirus (COVID-19): 16 March 2020. Available from: https://www.gov.uk/government/speeches/pm-statement-oncoronavirus-16-march-2020.

4. Boris Johnson. Prime Minister's statement on coronavirus (COVID-19): 23 March 2020. Available from: https://www.gov.uk/government/speeches/pm-address-to-the-nationon-coronavirus-23-march-2020.

5. Department for Transport, Grant Shapps. Face coverings to become mandatory on public transport. 4 June 2020. Available from: https://www.gov.uk/government/news/facecoverings-to-become-mandatory-on-public-transport.

6. Department of Health and Social Care, Matt Hancock. Face coverings to be mandatory in shops and supermarkets from 24 July 2020. 14 July 2020. Available from: https://www.gov.uk/government/speeches/face-coverings-to-be-mandatory-in-shops-andsupermarkets-from-24-july\#: :text=statement\%20to\%20Parliament,Face $\% 20$ coverings $\% 20$ to $\% 20 \mathrm{be} \% 20$ mandatory $\% 20 \mathrm{in} \% 20$ shops $\% 20$ and $\% 20$ supermarkets $\%$ 20from,supermarkets\%20from\%2024\%20July\%202020.

7. Cabinet Office. Coronavirus (COVID-19): What has changed - 22 September 2020. 22 September 2020. Available from: https://www.gov.uk/government/news/coronaviruscovid-19-what-has-changed-22-september.

8. Prime Minister confirms move to Step 4 [press release]. 12 July 2021. Available from: https://www.gov.uk/government/news/prime-minister-confirms-move-to-step-4.

9. Measures against Omicron variant come into effect: 30 November 2021 [press release]. 30 November 2021. Available from: https://www.gov.uk/government/news/measures-against-omicron-variant-come-into-effect30-november-2021. 
10. Prime Minister's Office 10 Downing Street. Prime Minister confirms move to Plan B in England 2021. 8 December 2021. Available from:

https://www.gov.uk/government/news/prime-minister-confirms-move-to-plan-b-in-england.

11. Smith LE, Potts HWW, Amlôt R, Fear N, Michie S, Rubin GJ. How has the emergence of the Omicron SARS-CoV-2 variant of concern influenced worry, perceived risk, and behaviour in the UK? The COVID-19 Rapid Survey of Adherence to Interventions and Responses (CORSAIR) study. Open Science Framework. 2021. DOI [pre-print]:

10.31219/osf.io/rpcu2.

12. Wright L, Steptoe A, Fancourt D. Trajectories of compliance with COVID19 related guidelines: longitudinal analyses of 50,000 UK adults MedRxiv. 2022. DOI [pre-print]: 10.1101/2021.04.13.21255336.

13. YouGov. Personal measures taken to avoid COVID-19. 2022. Available from: https://yougov.co.uk/topics/international/articles-reports/2020/03/17/personal-measurestaken-avoid-covid-19.

14. Davies R, Martin AF, Smith LE, Mowbray F, Woodland L, Amlot R, et al. The impact of "freedom day" on COVID-19 health protective behaviour in England: An observational study of hand hygiene, face covering use and physical distancing in public spaces pre and post the relaxing of restrictions. Open Science Framework. 2021. DOI [preprint]: 10.17605/OSF.IO/CK2U4.

15. Dennis J, Potter B, Ramsay T, Zarychanski R. The effects of provincial bicycle helmet legislation on helmet use and bicycle ridership in Canada. Inj Prev. 2010;16(4):21924.

16. Karkhaneh M, Kalenga JC, Hagel BE, Rowe BH. Effectiveness of bicycle helmet legislation to increase helmet use: a systematic review. Inj Prev. 2006;12(2):76-82.

17. Macpherson A, Spinks A. Bicycle helmet legislation for the uptake of helmet use and prevention of head injuries. Cochrane Database Syst Rev. 2008(3):CD005401.

18. Lally P, van Jaarsveld CHM, Potts HWW, Wardle J. How are habits formed: Modelling habit formation in the real world. European Journal of Social Psychology. 2010;40(6):998-1009. 
19. Judah G, Aunger R, Schmidt WP, Michie S, Granger S, Curtis V. Experimental pretesting of hand-washing interventions in a natural setting. Am J Public Health. 2009;99 Suppl 2:S405-11.

20. Smith LE, Potts HWW, Amlot R, Fear NT, Michie S, Rubin GJ. Adherence to the test, trace, and isolate system in the UK: results from 37 nationally representative surveys. BMJ. 2021;372:n608.

21. Office for National Statistics. Population estimates for the UK, England and Wales, Scotland and Northern Ireland: mid-2018 2019. 27 June 2019. Available from: https://www.ons.gov.uk/peoplepopulationandcommunity/populationandmigration/population estimates/bulletins/annualmidyearpopulationestimates/mid2018.

22. National Readership Survey. Social Grade. Available from: http://www.nrs.co.uk/nrsprint/lifestyle-and-classification-data/social-grade/.

23. .UK. Population of England and Wales. 7 August 2020. Available from: https://www.ethnicity-facts-figures.service.gov.uk/uk-population-by-ethnicity/national-andregional-populations/population-of-england-and-wales/latest\#by-ethnicity.

24. Georganas S. Mobile data shows which European countries took lockdown seriously. 28 May 2020. Available from: https://theconversation.com/mobile-data-shows-whicheuropean-countries-took-lockdown-seriously-138758.

25. Greater London Authority. Coronavirus (COVID-19) Mobility Report. 9 November 2020. Available from: https://data.london.gov.uk/dataset/coronavirus-covid-19-mobilityreport.

26. Laverty AA, Millett C, Majeed A, Vamos EP. COVID-19 presents opportunities and threats to transport and health. J R Soc Med. 2020;113(7):251-4.

27. Smith LE, Potts HWW, Amlôt R, Fear N, Michie S, Rubin GJ. How have patterns of social mixing changed during the pandemic? A series of cross-sectional nationally representative surveys. Open Science Framework. 2021.

28. Cabinet Office. New rules on staying at home and away from others. 23 March 2020. Available from:

https://assets.publishing.service.gov.uk/government/uploads/system/uploads/attachment_data /file/883116/Staying_at_home_and_away_from_others_social_distancing_.pdf. 
29. Cabinet Office. New National Restrictions from 5 November 2020. 31 October 2020. Available from: https://www.gov.uk/guidance/new-national-restrictions-from-5-november.

30. Statista. How often have you worn a face mask outside your home to protect yourself or others from coronavirus (COVID-19)? 2021. Available from:

https://www.statista.com/statistics/1114248/wearing-a-face-mask-outside-in-the-uk/.

31. Michie S, van Stralen MM, West R. The behaviour change wheel: a new method for characterising and designing behaviour change interventions. Implement Sci. 2011;6:42.

32. Gibson Miller J, Hartman TK, Levita L, Martinez AP, Mason L, McBride O, et al. Capability, opportunity, and motivation to enact hygienic practices in the early stages of the COVID-19 outbreak in the United Kingdom. British Journal of Health Psychology. 2020;25(4):856-64.

33. Kooistra EB, Van Rooij B. Pandemic Compliance: A systematic review of influences on social distancing behaviour during the first wave of the COVID-19 outbreak. PsyArXiv. 2020. DOI [pre-print]: 10.31234/osf.io/c5x2k.

34. Fisher KA, Barile JP, Guerin RJ, Vanden Esschert KL, Jeffers A, Tian LH, et al. Factors Associated with Cloth Face Covering Use Among Adults During the COVID-19 Pandemic - United States, April and May 2020. MMWR Morb Mortal Wkly Rep. 2020;69(28):933-7.

35. The Royal Society, The British Academy. Face masks and coverings for the general public: Behavioural knowledge, effectiveness of cloth coverings and public messaging. 2020 16 June 20. Available from: https://royalsociety.org/-/media/policy/projects/set-c/set-cfacemasks.pdf.

36. Dixon D, Den Daas C, Hubbard G, Johnston M. Using behavioural theory to understand adherence to behaviours that reduce transmission of COVID-19; evidence from the CHARIS representative national study. British Journal of Health Psychology. 2022;27(1):116-35.

37. World Health Organization. Pandemic fatigue: Reinvigorating the public to prevent COVID-19. 5 October 2020. Available from:

https://apps.who.int/iris/bitstream/handle/10665/335820/WHO-EURO-2020-1160-4090655390-eng.pdf. 
38. Reicher S, Drury J. Pandemic fatigue? How adherence to covid-19 regulations has been misrepresented and why it matters. BMJ Opinion. 2021.

39. Insitute of Global Health Innovation at Imperial College London, YouGov. COVID19 Global Behaviours and Attitudes; The Year in Review. 2021. Available from:

https://www.imperial.ac.uk/media/imperial-college/institute-of-global-health-innovation/FullYear_ICL-YouGov-Covid-19-Behaviour-Tracker_20212603_final.pdf.

40. Harvey N. Behavioural fatigue: Real phenomenon, naïve construct, or policy contrivance. Front Psychol. 2020.

41. Office for National Statistics. Internet users, UK: 2019. 2019. Available from: https://www.ons.gov.uk/businessindustryandtrade/itandinternetindustry/bulletins/internetuser s/2019.

42. Wright KB. Researching Internet-Based Populations Advantages and Disadvantages of Online Survey Research, Online Questionnaire Authoring Software Packages, and Web Survey Services. Journal of Computer-Mediated Communication [Internet]. 2005; DOI: 10.1111/j.1083-6101.2005.tb00259.x.

43. Timmons S, McGinnity F, Belton C, Barjakova M, Lunn P. It depends on how you ask: measuring bias in population surveys of compliance with COVID-19 public health guidance. J Epidemiol Community Health. 2020. 


\section{Supplementary materials 1 . Survey items.}

\section{$\underline{\text { Hand cleansing and wearing a face covering }}$}

Asked in wave 3 to wave 16. From wave 3 to wave 13 all participants answered this question. The sample was split in wave 14 to wave 16 with half of participants answering this question. In the past seven days have you...

- Washed your hands thoroughly and regularly with soap and water

- Done this, same amount as usual

- Done this, more than usual

- Not done this

- Not applicable

Asked in wave 14 to wave 30 . The sample was split in wave 14 to wave 16 with half of participants answering this question. From wave 17 to wave 30 all participants answered this question.

In the past seven days have you ...

- Washed your hands thoroughly and regularly with soap and water

- Worn a professional face mask when out and about

- Worn a homemade, cloth or improvised face mask (such as a scarf) when out and about

- Very Frequently

- Frequently

- Occasionally

- Rarely

- Never

- Not applicable

Asked in wave 31 to wave 50 to all participants.

In the past seven days have you ...

- Washed your hands thoroughly and regularly with soap and water, or used hand sanitising gel

- Worn a face mask or another face covering (such as a scarf) when out and about

- Very Frequently

- Frequently

- Occasionally

- Rarely

- Never

- Not applicable 


\section{Number of outings}

Asked from wave 10 to wave 50 to all participants.

Please enter the number of times you have been out of your home in the last seven days, for each of the following reasons?

If you have not left your home for this reason, please write 0

\section{RANDOMISE ORDER}

- To go to the shops, for groceries/pharmacy

- To go to the shops, for things other than groceries/pharmacy

- To go for a walk or some other exercise

- To spend time outdoors for recreational purposes (including to sit in parks etc.) [Item added in wave 17]

- To go out to work

- To meet up with friends and/or family that you don't live with

- To go to a restaurant, café or pub [Item added in wave 24]

OPEN - NUMERICAL VALUE ONLY

Asked from wave 51 onwards to all participants.

Q8_C. How many times have you done each of the following activities in the past seven days?

Please give an approximate number if you are unsure. If you have not done the activity at all in the last seven days, please write 0.

\section{RANDOMISE ORDER}

- Been to the shops, for groceries/pharmacy

- Been to the shops, for things other than groceries/pharmacy

- Spent time outdoors for exercise or recreational purposes (including to sit in parks etc.)

- Left the house to go out to work (number of days)

- Met up with friends and/or family that you don't live with

- Been to a restaurant, café or pub

OPEN - NUMERICAL VALUE ONLY 


\section{Supplementary materials 2. Associations with survey wave.}

Results reported here use are for all participants with a valid individual response ID.

Individual response IDs were only collected from 17 February 2020 (wave 4) onwards, therefore all participants from data collected 10 to 13 February 2020 (wave 3, n=2006) were excluded. Individual response ID was not collected for a small number of participants in subsequent waves, participants were excluded ( $n=743,0.6 \%$, wave 4 to 66 ). Therefore, point percentages may differ slightly from those reported in the main text.

All generalised estimating equations (GEEs) were run using an unstructured correlation matrix, unless otherwise specified.

Table 1. Associations between more frequent hand washing and survey wave, between February and May 2020.

\begin{tabular}{|c|c|c|c|c|}
\hline Survey wave & $\begin{array}{l}\text { Not more } \\
\text { frequent } \\
\text { hand } \\
\text { washing } \\
\text { [total } \\
\mathrm{n}=9,442 \text { ], n } \\
(\%)\end{array}$ & $\begin{array}{l}\text { More frequent } \\
\text { hand washing } \\
\text { [total } \\
\mathrm{n}=13,315], \mathrm{n} \\
(\%)\end{array}$ & Odds ratio $(95 \% \mathrm{CI})$ & $\mathrm{p}$-value \\
\hline Overall & - & - & $\chi^{2}(12)=2725.8$ & $<0.001$ \\
\hline 17 to 20 February 2020 (wave 4$) \dagger$ & $1530(77.7)$ & $440(22.3)$ & Reference & Reference \\
\hline 24 to 27 February 2020 (wave 5) & $1468(74.3)$ & $508(25.7)$ & $1.20(1.04$ to 1.39$)$ & 0.01 \\
\hline 2 to 5 March 2020 (wave 6 ) & $1085(54.6)$ & $901(45.4)$ & $2.88(2.51$ to 3.30$)$ & $<0.001$ \\
\hline 9 to 11 March 2020 (wave 7 ) & $997(50.3)$ & $987(49.7)$ & $3.42(2.98$ to 3.92$)$ & $<0.001$ \\
\hline 16 to 18 March 2020 (wave 8) & $723(36.5)$ & $1259(63.5)$ & $6.04(5.26$ to 6.94$)$ & $<0.001$ \\
\hline 23 to 25 March 2020 (wave 9) & $600(30.1)$ & $1392(69.9)$ & $8.04(6.98$ to 9.26$)$ & $<0.001$ \\
\hline 30 March to 1 April 2020 (wave 10) & $536(27.1)$ & $1444(72.9)$ & $9.33(8.08$ to 10.78$)$ & $<0.001$ \\
\hline 6 to 8 April 2020 (wave 11 ) & $528(26.8)$ & $1440(73.2)$ & $9.46(8.18$ to 10.93$)$ & $<0.001$ \\
\hline 14 to 15 April 2020 (wave 12 ) & $521(26.4)$ & $1455(73.6)$ & $9.60(8.31$ to 11.08$)$ & $<0.001$ \\
\hline 20 to 22 April 2020 (wave 13 ) & $580(29.4)$ & $1393(70.6)$ & $8.36(7.25$ to 9.64$)$ & $<0.001$ \\
\hline 27 to 29 April 2020 (wave 14 ) & $281(28.5)$ & $705(71.5)$ & $8.63(7.26$ to 10.24$)$ & $<0.001$ \\
\hline 4 to 6 May 2020 (wave 15 ) & $293(29.2)$ & $712(70.8)$ & $8.36(7.06$ to 9.90$)$ & $<0.001$ \\
\hline 11 to 13 May 2020 (wave 16 ) & $300(30.6)$ & $679(69.4)$ & $8.04(6.79$ to 9.53$)$ & $<0.001$ \\
\hline
\end{tabular}


Table 2. Associations between frequent hand washing and survey wave, between April 2020 and May 2021.

\begin{tabular}{|c|c|c|c|c|}
\hline Survey wave & $\begin{array}{l}\text { Infrequent } \\
\text { hand } \\
\text { washing } \\
\text { [total } \\
\mathrm{n}=8,637], \mathrm{n} \\
(\%)\end{array}$ & $\begin{array}{l}\text { Frequent hand } \\
\text { washing } \\
{[\mathrm{n}=62,514], \mathrm{n}} \\
(\%)\end{array}$ & Odds ratio $(95 \% \mathrm{CI})$ & p-value \\
\hline Overall & - & - & $\chi^{2}(36)=117.2$ & $<0.001$ \\
\hline 27 to 29 April 2020 (wave 14 ) & $97(9.8)$ & $895(90.2)$ & Reference & Reference \\
\hline 4 to 6 May 2020 (wave 15 ) & $96(9.6)$ & $900(90.4)$ & $1.11(0.84$ to 1.47$)$ & 0.47 \\
\hline 11 to 13 May 2020 (wave 16 ) & $120(12.0)$ & $877(88.0)$ & $0.89(0.68$ to 1.17$)$ & 0.40 \\
\hline 18 to 20 May 2020 (wave 17 ) & $232(11.7)$ & $1749(88.3)$ & $0.92(0.72$ to 1.17$)$ & 0.48 \\
\hline 26 to 27 May 2020 (wave 18 ) & 249 (12.6) & $1730(87.4)$ & 0.84 (0.66 to 1.07$)$ & 0.16 \\
\hline 1 to 3 June 2020 (wave 19) & $244(12.3)$ & $1732(87.7)$ & $0.88(0.69$ to 1.11$)$ & 0.27 \\
\hline 8 to 10 June 2020 (wave 20 ) & $208(10.5)$ & $1772(89.5)$ & $1.02(0.80$ to 1.29$)$ & 0.90 \\
\hline 15 to 17 June 2020 (wave 21 ) & $267(13.5)$ & $1713(86.5)$ & $0.78(0.61$ to 0.98$)$ & 0.03 \\
\hline 22 to 24 June 2020 (wave 22) & $240(12.1)$ & $1744(87.9)$ & $0.87(0.69$ to 1.11$)$ & 0.26 \\
\hline 29 June to 1 July 2020 (wave 23) & $260(13.1)$ & $1721(86.9)$ & 0.80 (0.63 to 1.02$)$ & 0.07 \\
\hline 6 to 8 July 2020 (wave 24 ) & $264(13.3)$ & $1721(86.7)$ & $0.81(0.64$ to 1.03$)$ & 0.08 \\
\hline 20 to 22 July 2020 (wave 25 ) & $265(13.3)$ & $1722(86.7)$ & $0.78(0.61$ to 0.98$)$ & 0.03 \\
\hline 3 to 5 August 2020 (wave 26) & $265(13.4)$ & $1714(86.6)$ & 0.77 (0.61 to 0.97$)$ & 0.03 \\
\hline 1 to 2 September 2020 (wave 27) & $238(11.9)$ & $1760(88.1)$ & $0.88(0.69$ to 1.13$)$ & 0.31 \\
\hline 14 to 16 September 2020 (wave 28) & $203(10.2)$ & $1794(89.8)$ & $1.04(0.82$ to 1.33$)$ & 0.74 \\
\hline 28 to 30 September 2020 (wave 29 ) & $228(11.3)$ & $1796(88.7)$ & $0.93(0.73$ to 1.19$)$ & 0.59 \\
\hline 12 to 14 October 2020 (wave 30 ) & $205(10.0)$ & $1854(90.0)$ & $1.08(0.84$ to 1.38$)$ & 0.55 \\
\hline 26 to 28 October 2020 (wave 31 ) & $226(11.1)$ & $1805(88.9)$ & $0.94(0.74$ to 1.20$)$ & 0.63 \\
\hline 9 to 11 November 2020 (wave 32) & $210(10.4)$ & $1811(89.6)$ & $1.02(0.80$ to 1.31$)$ & 0.85 \\
\hline 16 to 18 November 2020 (wave 33 ) & $258(12.6)$ & $1784(87.4)$ & $0.83(0.66$ to 1.06$)$ & 0.13 \\
\hline 23 to 25 November 2020 (wave 34 ) & $236(11.7)$ & $1775(88.3)$ & $0.90(0.71$ to 1.14$)$ & 0.38 \\
\hline $\begin{array}{l}30 \text { November to } 2 \text { December } 2020 \\
\text { (wave } 35 \text { ) }\end{array}$ & $246(12.1)$ & $1789(87.9)$ & $0.88(0.69$ to 1.11$)$ & 0.28 \\
\hline 7 to 9 December 2020 (wave 36) & $232(11.1)$ & $1853(88.9)$ & $0.95(0.75$ to 1.21$)$ & 0.68 \\
\hline 14 to 16 December 2020 (wave 37 ) & $249(12.4)$ & $1757(87.6)$ & $0.84(0.66$ to 1.07$)$ & 0.16 \\
\hline 21 to 23 December 2020 (wave 38) & $248(12.5)$ & $1742(87.5)$ & $0.84(0.66$ to 1.06$)$ & 0.15 \\
\hline 28 to 30 December 2020 (wave 39) & $226(11.2)$ & $1786(88.8)$ & $0.94(0.74$ to 1.20$)$ & 0.62 \\
\hline 4 to 6 January 2021 (wave 40) & $219(10.8)$ & $1808(89.2)$ & $0.99(0.77$ to 1.26$)$ & 0.93 \\
\hline 11 to 13 January 2021 (wave 41 ) & $232(11.7)$ & $1757(88.3)$ & $0.91(0.71$ to 1.15$)$ & 0.43 \\
\hline 25 to 27 January 2021 (wave 42 ) & 237 (11.9) & $1759(88.1)$ & $0.89(0.70$ to 1.13$)$ & 0.35 \\
\hline 8 to 10 February 2021 (wave 43) & 254 (12.7) & $1752(87.3)$ & $0.82(0.65$ to 1.05$)$ & 0.11 \\
\hline 22 to 24 February 2021 (wave 44 ) & $223(11.1)$ & $1779(88.9)$ & $0.96(0.75$ to 1.22$)$ & 0.71 \\
\hline 8 to 10 March 2021 (wave 45 ) & $242(12.1)$ & $1757(87.9)$ & $0.86(0.68$ to 1.09$)$ & 0.22 \\
\hline 22 to 24 March 2021 (wave 46) & $281(13.8)$ & $1762(86.2)$ & $0.75(0.59$ to 0.95$)$ & 0.02 \\
\hline 5 to 7 April 2021 (wave 47) & $284(14.2)$ & $1712(85.8)$ & $0.73(0.57$ to 0.92$)$ & 0.01 \\
\hline 19 to 21 April 2021 (wave 48 ) & $293(14.7)$ & $1695(85.3)$ & $0.69(0.55$ to 0.88$)$ & 0.002 \\
\hline 4 to 5 May 2021 (wave 49) & $268(13.5)$ & $1724(86.5)$ & $0.77(0.61$ to 0.98$)$ & 0.03 \\
\hline 17 to 19 May 2021 (wave 50 ) & $292(14.6)$ & $1713(85.4)$ & $0.69(0.55$ to 0.88$)$ & 0.002 \\
\hline
\end{tabular}


Table 3. Associations between total outings for shopping, and to see people from another household and survey wave, between April 2020 and May 2021.

\begin{tabular}{|c|c|c|c|}
\hline Survey wave & $\begin{array}{l}\text { Number of responses, mean number } \\
\text { of outings, SD [total } n=70,493 \text { ] }\end{array}$ & $\begin{array}{l}\text { Incidence rate ratio } \\
(95 \% \mathrm{CI})\end{array}$ & $\mathrm{p}$-value \\
\hline Overall & - & $\chi^{2}(40)=2559.7$ & $<0.001$ \\
\hline $\begin{array}{l}30 \text { March to } 1 \text { April } 2020 \text { (wave } \\
\text { 10) }\end{array}$ & $\mathrm{N}=1739, \mathrm{M}=2.1, \mathrm{SD}=2.7$ & Reference & Reference \\
\hline 6 to 8 April 2020 (wave 11) & $\mathrm{N}=1738, \mathrm{M}=2.0, \mathrm{SD}=3.3$ & $0.95(0.86$ to 1.04$)$ & 0.24 \\
\hline 14 to 15 April 2020 (wave 12 ) & $\mathrm{N}=1742, \mathrm{M}=1.9, \mathrm{SD}=2.8$ & $0.90(0.82$ to 0.98$)$ & 0.01 \\
\hline 20 to 22 April 2020 (wave 13) & $\mathrm{N}=1735, \mathrm{M}=2.1, \mathrm{SD}=3.1$ & $0.98(0.90$ to 1.07$)$ & 0.71 \\
\hline 27 to 29 April (wave 14) & $\mathrm{N}=1698, \mathrm{M}=2.1, \mathrm{SD}=3.3$ & $0.98(0.90$ to 1.08$)$ & 0.71 \\
\hline 4 to 6 May 2020 (wave 15 ) & $\mathrm{N}=1724, \mathrm{M}=2.0, \mathrm{SD}=2.8$ & $0.95(0.87$ to 1.03$)$ & 0.24 \\
\hline 11 to 13 May 2020 (wave 16 ) & $\mathrm{N}=1742, \mathrm{M}=2.3, \mathrm{SD}=3.7$ & $1.12(1.02$ to 1.22$)$ & 0.01 \\
\hline 18 to 20 May 2020 (wave 17 ) & $\mathrm{N}=1716, \mathrm{M}=2.4, \mathrm{SD}=3.0$ & $1.14(1.05$ to 1.23$)$ & 0.001 \\
\hline 26 to 27 May 2020 (wave 18 ) & $\mathrm{N}=1721, \mathrm{M}=2.6, \mathrm{SD}=3.4$ & $1.25(1.15$ to 1.35$)$ & $<0.001$ \\
\hline 1 to 3 June 2020 (wave 19) & $\mathrm{N}=1703, \mathrm{M}=2.7, \mathrm{SD}=3.2$ & $1.28(1.19$ to 1.38$)$ & $<0.001$ \\
\hline 8 to 10 June 2020 (wave 20 ) & $\mathrm{N}=1708, \mathrm{M}=3.0, \mathrm{SD}=3.9$ & $1.41(1.30$ to 1.52$)$ & $<0.001$ \\
\hline 15 to 17 June 2020 (wave 21 ) & $\mathrm{N}=1757, \mathrm{M}=3.2, \mathrm{SD}=3.9$ & $1.52(1.40$ to 1.64$)$ & $<0.001$ \\
\hline 22 to 24 June 2020 (wave 22 ) & $\mathrm{N}=1725, \mathrm{M}=3.4, \mathrm{SD}=4.2$ & $1.62(1.50$ to 1.75$)$ & $<0.001$ \\
\hline 29 June to 1 July 2020 (wave 23 ) & $\mathrm{N}=1726, \mathrm{M}=3.4, \mathrm{SD}=4.5$ & $1.62(1.50$ to 1.76$)$ & $<0.001$ \\
\hline 6 to 8 July 2020 (wave 24 ) & $\mathrm{N}=1712, \mathrm{M}=3.5, \mathrm{SD}=4.3$ & $1.69(1.56$ to 1.82$)$ & $<0.001$ \\
\hline 20 to 22 July 2020 (wave 25 ) & $\mathrm{N}=1717, \mathrm{M}=3.9, \mathrm{SD}=4.5$ & $1.85(1.71$ to 2.00$)$ & $<0.001$ \\
\hline 3 to 5 August 2020 (wave 26) & $\mathrm{N}=1723, \mathrm{M}=4.2, \mathrm{SD}=5.3$ & $1.97(1.82$ to 2.14$)$ & $<0.001$ \\
\hline 1 to 2 September 2020 (wave 27) & $\mathrm{N}=1745, \mathrm{M}=4.2, \mathrm{SD}=4.5$ & $1.97(1.83$ to 2.13$)$ & $<0.001$ \\
\hline $\begin{array}{l}14 \text { to } 16 \text { September } 2020 \text { (wave } \\
28 \text { ) }\end{array}$ & $\mathrm{N}=1719, \mathrm{M}=4.2, \mathrm{SD}=4.3$ & $1.96(1.82$ to 2.11$)$ & $<0.001$ \\
\hline $\begin{array}{l}28 \text { to } 30 \text { September } 2020 \text { (wave } \\
\text { 29) }\end{array}$ & $\mathrm{N}=1702, \mathrm{M}=3.9, \mathrm{SD}=4.2$ & 1.83 (1.69 to 1.97$)$ & $<0.001$ \\
\hline 12 to 14 October 2020 (wave 30 ) & $\mathrm{N}=1780, \mathrm{M}=4.0, \mathrm{SD}=4.4$ & 1.88 (1.74 to 2.02$)$ & $<0.001$ \\
\hline 26 to 28 October 2020 (wave 31 ) & $\mathrm{N}=1728, \mathrm{M}=3.7, \mathrm{SD}=4.0$ & 1.74 (1.61 to 1.87$)$ & $<0.001$ \\
\hline 9 to 11 November 2020 (wave 32) & $\mathrm{N}=1713, \mathrm{M}=3.4, \mathrm{SD}=4.5$ & $1.57(1.44$ to 1.70$)$ & $<0.001$ \\
\hline $\begin{array}{l}16 \text { to } 18 \text { November } 2020 \text { (wave } \\
33 \text { ) }\end{array}$ & $\mathrm{N}=1779, \mathrm{M}=3.4, \mathrm{SD}=4.6$ & $1.56(1.43$ to 1.70$)$ & $<0.001$ \\
\hline $\begin{array}{l}23 \text { to } 25 \text { November } 2020 \text { (wave } \\
34 \text { ) }\end{array}$ & $\mathrm{N}=1731, \mathrm{M}=3.4, \mathrm{SD}=4.6$ & $1.58(1.45$ to 1.72$)$ & $<0.001$ \\
\hline $\begin{array}{l}30 \text { November to } 2 \text { December } \\
2020 \text { (wave } 35 \text { ) }\end{array}$ & $\mathrm{N}=1779, \mathrm{M}=3.6, \mathrm{SD}=4.8$ & 1.68 (1.54 to 1.82$)$ & $<0.001$ \\
\hline 7 to 9 December 2020 (wave 36) & $\mathrm{N}=1779, \mathrm{M}=3.5, \mathrm{SD}=4.0$ & $1.65(1.53$ to 1.78$)$ & $<0.001$ \\
\hline $\begin{array}{l}14 \text { to } 16 \text { December } 2020 \text { (wave } \\
\text { 37) }\end{array}$ & $\mathrm{N}=1694, \mathrm{M}=3.4, \mathrm{SD}=4.2$ & $1.60(1.48$ to 1.74$)$ & $<0.001$ \\
\hline $\begin{array}{l}21 \text { to } 23 \text { December } 2020 \text { (wave } \\
\text { 38) }\end{array}$ & $\mathrm{N}=1701, \mathrm{M}=3.5, \mathrm{SD}=4.3$ & 1.63 (1.51 to 1.77$)$ & $<0.001$ \\
\hline $\begin{array}{l}28 \text { to } 30 \text { December } 2020 \text { (wave } \\
\text { 39) }\end{array}$ & $\mathrm{N}=1736, \mathrm{M}=3.4, \mathrm{SD}=4.3$ & $1.59(1.47$ to 1.73$)$ & $<0.001$ \\
\hline 4 to 6 January 2021 (wave 40 ) & $\mathrm{N}=1738, \mathrm{M}=3.0, \mathrm{SD}=3.8$ & $1.39(1.28$ to 1.51$)$ & $<0.001$ \\
\hline 11 to 13 January 2021 (wave 41 ) & $\mathrm{N}=1708, \mathrm{M}=2.5, \mathrm{SD}=3.2$ & $1.15(1.06$ to 1.25$)$ & 0.001 \\
\hline 25 to 27 January 2021 (wave 42 ) & $\mathrm{N}=1712, \mathrm{M}=2.8, \mathrm{SD}=4.4$ & $1.29(1.18$ to 1.41$)$ & $<0.001$ \\
\hline 8 to 10 February 2021 (wave 43 ) & $\mathrm{N}=1696, \mathrm{M}=2.8, \mathrm{SD}=3.6$ & $1.28(1.18$ to 1.40$)$ & $<0.001$ \\
\hline 22 to 24 February 2021 (wave 44 ) & $\mathrm{N}=1660, \mathrm{M}=3.6, \mathrm{SD}=5.3$ & $1.65(1.50$ to 1.80$)$ & $<0.001$ \\
\hline 8 to 10 March 2021 (wave 45 ) & $\mathrm{N}=1713, \mathrm{M}=3.2, \mathrm{SD}=4.3$ & $1.49(1.37$ to 1.62$)$ & $<0.001$ \\
\hline 22 to 24 March 2021 (wave 46) & $\mathrm{N}=1731, \mathrm{M}=3.6, \mathrm{SD}=5.0$ & $1.68(1.54$ to 1.83$)$ & $<0.001$ \\
\hline 5 to 7 April 2021 (wave 47) & $\mathrm{N}=1666, \mathrm{M}=4.0, \mathrm{SD}=4.6$ & 1.84 (1.70 to 1.98$)$ & $<0.001$ \\
\hline 19 to 21 April 2021 (wave 48 ) & $\mathrm{N}=1662, \mathrm{M}=4.2, \mathrm{SD}=4.8$ & $1.95(1.80$ to 2.11$)$ & $<0.001$ \\
\hline 4 to 5 May 2021 (wave 49) & $\mathrm{N}=1636, \mathrm{M}=4.2, \mathrm{SD}=4.5$ & $1.94(1.80$ to 2.10$)$ & $<0.001$ \\
\hline 17 to 19 May 2021 (wave 50 ) & $\mathrm{N}=1659, \mathrm{M}=4.2, \mathrm{SD}=4.4$ & 1.97 (1.83 to 2.12$)$ & $<0.001$ \\
\hline
\end{tabular}


Table 4. Associations between total outings for shopping, and to see people from another household and survey wave, between June 2021 and January 2022.

\begin{tabular}{|c|c|c|c|}
\hline Survey wave & $\begin{array}{l}\text { Number of responses, mean number } \\
\text { of outings, SD [total } n=29,607]\end{array}$ & $\begin{array}{l}\text { Incidence rate ratio } \\
(95 \% \mathrm{CI})\end{array}$ & p-value \\
\hline Overall & - & $\chi^{2}(16)=87.7$ & $<0.001$ \\
\hline 1 to 2 June 2021 (wave 51 ) & $\mathrm{N}=1697, \mathrm{M}=4.9, \mathrm{SD}=4.4$ & $0.91(0.85$ to 0.97$)$ & 0.004 \\
\hline 14 to 16 June 2021 (wave 52 ) & $\mathrm{N}=1670, \mathrm{M}=4.8, \mathrm{SD}=4.5$ & $0.88(0.82$ to 0.94$)$ & $<0.001$ \\
\hline 28 to 29 June 2021 (wave 53) & $\mathrm{N}=1704, \mathrm{M}=4.8, \mathrm{SD}=4.4$ & $0.88(0.82$ to 0.94$)$ & $<0.001$ \\
\hline 26 to 27 July 2021 (wave 54) & $\mathrm{N}=1732, \mathrm{M}=4.9, \mathrm{SD}=4.5$ & $0.91(0.85$ to 0.97$)$ & 0.004 \\
\hline 9 to 10 August 2021 (wave 55) & $\mathrm{N}=1706, \mathrm{M}=5.1, \mathrm{SD}=4.8$ & $0.94(0.88$ to 1.01$)$ & 0.08 \\
\hline 23 to 24 August 2021 (wave 56) & $\mathrm{N}=1719, \mathrm{M}=5.2, \mathrm{SD}=4.8$ & $0.96(0.90$ to 1.03$)$ & 0.22 \\
\hline 6 to 7 September 2021 (wave 57) & $\mathrm{N}=1723, \mathrm{M}=4.9, \mathrm{SD}=4.6$ & $0.90(0.84$ to 0.96$)$ & 0.003 \\
\hline $\begin{array}{l}20 \text { to } 22 \text { September } 2021 \text { (wave } \\
58 \text { ) }\end{array}$ & $\mathrm{N}=1632, \mathrm{M}=5.3, \mathrm{SD}=6.1$ & $1.00(0.93$ to 1.08$)$ & 0.97 \\
\hline 4 to 6 October 2021 (wave 59) & $\mathrm{N}=1685, \mathrm{M}=5.4, \mathrm{SD}=6.4$ & $1.00(0.92$ to 1.08$)$ & 0.96 \\
\hline 18 to 20 October 2021 (wave 60 ) & $\mathrm{N}=1590, \mathrm{M}=5.2, \mathrm{SD}=5.9$ & $0.96(0.89$ to 1.04$)$ & 0.34 \\
\hline 1 to 4 November 2021 (wave 61) & $\mathrm{N}=1833, \mathrm{M}=5.3, \mathrm{SD}=6.2$ & $0.99(0.92$ to 1.06$)$ & 0.70 \\
\hline $\begin{array}{l}15 \text { to } 17 \text { November } 2021 \text { (wave } \\
62 \text { ) }\end{array}$ & $\mathrm{N}=1864, \mathrm{M}=5.9, \mathrm{SD}=7.4$ & 1.09 (1.01 to 1.17$)$ & 0.04 \\
\hline $\begin{array}{l}29 \text { November to } 1 \text { December } \\
2021 \text { (wave 63) }\end{array}$ & $\mathrm{N}=1743, \mathrm{M}=5.1, \mathrm{SD}=6.1$ & $0.95(0.89$ to 1.03$)$ & 0.21 \\
\hline $\begin{array}{l}6 \text { to } 8 \text { December } 2021 \text { (wave } \\
63.5 \text { ) }\end{array}$ & $\mathrm{N}=1679, \mathrm{M}=5.5, \mathrm{SD}=6.2$ & $1.02(0.95$ to 1.10$)$ & 0.60 \\
\hline $\begin{array}{l}13 \text { to } 16 \text { December } 2021 \text { (wave } \\
64 \text { ) }\end{array}$ & $\mathrm{N}=1841, \mathrm{M}=5.3, \mathrm{SD}=6.0$ & $0.97(0.90$ to 1.05$)$ & 0.48 \\
\hline 4 to 6 January 2022 (wave 65 ) & $\mathrm{N}=1876, \mathrm{M}=4.8, \mathrm{SD}=5.5$ & $0.88(0.82$ to 0.95$)$ & 0.001 \\
\hline 17 to 20 January 2022 (wave 66 ) & $\mathrm{N}=1913, \mathrm{M}=5.4, \mathrm{SD}=6.5$ & Reference & Reference \\
\hline
\end{tabular}


Table 5. Associations between total outings for shopping, to see people from another household, and to go to a restaurant/café/pub and survey wave, between July 2020 and May 2021.

\begin{tabular}{|c|c|c|c|}
\hline Survey wave & $\begin{array}{l}\text { Number of responses, mean number } \\
\text { of outings, SD [total } n=46,319 \text { ] }\end{array}$ & $\begin{array}{l}\text { Incidence rate ratio } \\
(95 \% \mathrm{CI})\end{array}$ & $\mathrm{p}$-value \\
\hline Overall & - & $\chi^{2}(26)=937.6$ & $<0.001$ \\
\hline 6 to 8 July 2020 (wave 24 ) & $\mathrm{N}=1712, \mathrm{M}=3.8, \mathrm{SD}=4.8$ & $0.81(0.75$ to 0.87$)$ & $<0.001$ \\
\hline 20 to 22 July 2020 (wave 25 ) & $\mathrm{N}=1717, \mathrm{M}=4.5, \mathrm{SD}=5.3$ & $0.95(0.89$ to 1.02$)$ & 0.19 \\
\hline 3 to 5 August 2020 (wave 26) & $\mathrm{N}=1723, \mathrm{M}=4.9, \mathrm{SD}=6.2$ & $1.03(0.95$ to 1.11$)$ & 0.46 \\
\hline 1 to 2 September 2020 (wave 27) & $\mathrm{N}=1745, \mathrm{M}=5.2, \mathrm{SD}=5.3$ & $1.09(1.02$ to 1.17$)$ & 0.01 \\
\hline $\begin{array}{l}14 \text { to } 16 \text { September } 2020 \text { (wave } \\
28 \text { ) }\end{array}$ & $\mathrm{N}=1719, \mathrm{M}=5.0, \mathrm{SD}=5.1$ & $1.05(0.98$ to 1.12$)$ & 0.21 \\
\hline $\begin{array}{l}28 \text { to } 30 \text { September } 2020 \text { (wave } \\
29 \text { ) }\end{array}$ & $\mathrm{N}=1702, \mathrm{M}=4.6, \mathrm{SD}=5.3$ & $0.98(0.91$ to 1.05$)$ & 0.59 \\
\hline 12 to 14 October 2020 (wave 30) & $\mathrm{N}=1780, \mathrm{M}=4.7, \mathrm{SD}=5.2$ & $0.99(0.93$ to 1.07$)$ & 0.86 \\
\hline 26 to 28 October 2020 (wave 31 ) & $\mathrm{N}=1728, \mathrm{M}=4.3, \mathrm{SD}=4.8$ & $0.92(0.86$ to 0.99$)$ & 0.02 \\
\hline 9 to 11 November 2020 (wave 32) & $\mathrm{N}=1713, \mathrm{M}=3.7, \mathrm{SD}=5.1$ & $0.78(0.72$ to 0.85$)$ & $<0.001$ \\
\hline $\begin{array}{l}16 \text { to } 18 \text { November } 2020 \text { (wave } \\
33 \text { ) }\end{array}$ & $\mathrm{N}=1779, \mathrm{M}=3.6, \mathrm{SD}=5.6$ & $0.76(0.70$ to 0.83$)$ & $<0.001$ \\
\hline $\begin{array}{l}23 \text { to } 25 \text { November } 2020 \text { (wave } \\
34 \text { ) }\end{array}$ & $\mathrm{N}=1731, \mathrm{M}=3.6, \mathrm{SD}=5.2$ & 0.75 (0.69 to 0.82$)$ & $<0.001$ \\
\hline $\begin{array}{l}30 \text { November to } 2 \text { December } \\
2020 \text { (wave } 35 \text { ) }\end{array}$ & $\mathrm{N}=1779, \mathrm{M}=3.8, \mathrm{SD}=5.8$ & $0.81(0.74$ to 0.88$)$ & $<0.001$ \\
\hline 7 to 9 December 2020 (wave 36) & $\mathrm{N}=1779, \mathrm{M}=3.8, \mathrm{SD}=4.5$ & $0.81(0.76$ to 0.87$)$ & $<0.001$ \\
\hline $\begin{array}{l}14 \text { to } 16 \text { December } 2020 \text { (wave } \\
\text { 37) }\end{array}$ & $\mathrm{N}=1694, \mathrm{M}=3.7, \mathrm{SD}=4.5$ & $0.80(0.74$ to 0.86$)$ & $<0.001$ \\
\hline $\begin{array}{l}21 \text { to } 23 \text { December } 2020 \text { (wave } \\
\text { 38) }\end{array}$ & $\mathrm{N}=1701, \mathrm{M}=3.8, \mathrm{SD}=5.1$ & $0.81(0.75$ to 0.88$)$ & $<0.001$ \\
\hline $\begin{array}{l}28 \text { to } 30 \text { December } 2020 \text { (wave } \\
\text { 39) }\end{array}$ & $\mathrm{N}=1736, \mathrm{M}=3.6, \mathrm{SD}=4.8$ & $0.77(0.71$ to 0.83$)$ & $<0.001$ \\
\hline 4 to 6 January 2021 (wave 40 ) & $\mathrm{N}=1738, \mathrm{M}=3.2, \mathrm{SD}=4.4$ & $0.67(0.62$ to 0.73$)$ & $<0.001$ \\
\hline 11 to 13 January 2021 (wave 41 ) & $\mathrm{N}=1708, \mathrm{M}=2.6, \mathrm{SD}=3.7$ & $0.56(0.51$ to 0.60$)$ & $<0.001$ \\
\hline 25 to 27 January 2021 (wave 42 ) & $\mathrm{N}=1712, \mathrm{M}=2.9, \mathrm{SD}=4.9$ & $0.62(0.57$ to 0.68$)$ & $<0.001$ \\
\hline 8 to 10 February 2021 (wave 43 ) & $\mathrm{N}=1696, \mathrm{M}=2.9, \mathrm{SD}=3.9$ & $0.61(0.56$ to 0.66$)$ & $<0.001$ \\
\hline 22 to 24 February 2021 (wave 44 ) & $\mathrm{N}=1660, \mathrm{M}=3.7, \mathrm{SD}=5.6$ & $0.78(0.72$ to 0.85$)$ & $<0.001$ \\
\hline 8 to 10 March 2021 (wave 45 ) & $\mathrm{N}=1713, \mathrm{M}=3.4, \mathrm{SD}=4.9$ & $0.72(0.66$ to 0.78$)$ & $<0.001$ \\
\hline 22 to 24 March 2021 (wave 46) & $\mathrm{N}=1731, \mathrm{M}=3.8, \mathrm{SD}=5.4$ & $0.80(0.74$ to 0.87$)$ & $<0.001$ \\
\hline 5 to 7 April 2021 (wave 47) & $\mathrm{N}=1666, \mathrm{M}=4.2, \mathrm{SD}=5.0$ & $0.87(0.81$ to 0.94$)$ & $<0.001$ \\
\hline 19 to 21 April 2021 (wave 48) & $\mathrm{N}=1662, \mathrm{M}=4.6, \mathrm{SD}=5.3$ & $0.98(0.91$ to 1.05$)$ & 0.57 \\
\hline 4 to 5 May 2021 (wave 49) & $\mathrm{N}=1636, \mathrm{M}=4.7, \mathrm{SD}=5.1$ & $0.99(0.92$ to 1.06$)$ & 0.80 \\
\hline 17 to 19 May 2021 (wave 50) & $\mathrm{N}=1659, \mathrm{M}=4.7, \mathrm{SD}=5.0$ & Reference & Reference \\
\hline
\end{tabular}


Table 6. Associations between total outings for shopping, to see people from another household, and to go to a restaurant/café/pub and survey wave, between June 2021 and January 2022.

\begin{tabular}{llll}
\hline Survey wave & $\begin{array}{l}\text { Number of responses, mean number } \\
\text { of outings, } \mathrm{SD} \text { [total } \mathrm{n}=29,607]\end{array}$ & $\begin{array}{l}\text { Incidence rate ratio } \\
\text { (95\% } \mathrm{CI})\end{array}$ & p-value \\
\hline Overall & - & $\chi^{2}(16)=108.6$ & $<0.001$ \\
\hline 1 to 2 June 2021 (wave 51) & $\mathrm{N}=1697, \mathrm{M}=5.7, \mathrm{SD}=4.9$ & $0.89(0.84$ to 0.95$)$ & 0.001 \\
14 to 16 June 2021 (wave 52) & $\mathrm{N}=1670, \mathrm{M}=5.6, \mathrm{SD}=5.3$ & $0.87(0.82$ to 0.93$)$ & $<0.001$ \\
28 to 29 June 2021 (wave 53) & $\mathrm{N}=1704, \mathrm{M}=5.7, \mathrm{SD}=5.3$ & $0.88(0.82$ to 0.94$)$ & $<0.001$ \\
26 to 27 July 2021 (wave 54) & $\mathrm{N}=1732, \mathrm{M}=5.9, \mathrm{SD}=5.5$ & $0.91(0.85$ to 0.97$)$ & 0.007 \\
9 to 10 August 2021 (wave 55) & $\mathrm{N}=1706, \mathrm{M}=6.1, \mathrm{SD}=5.6$ & $0.94(0.88$ to 1.01$)$ & 0.07 \\
23 to 24 August 2021 (wave 56) & $\mathrm{N}=1719, \mathrm{M}=6.2, \mathrm{SD}=5.6$ & $0.96(0.90$ to 1.03$)$ & 0.24 \\
6 to 7 September 2021 (wave 57) & $\mathrm{N}=1723, \mathrm{M}=5.8, \mathrm{SD}=5.4$ & $0.91(0.85$ to 0.97$)$ & 0.005 \\
20 to 22 September 2021 (wave & $\mathrm{N}=1632, \mathrm{M}=6.4, \mathrm{SD}=7.1$ & $1.02(0.95$ to 1.10$)$ & 0.57 \\
58) & & & \\
4 to 6 October 2021 (wave 59) & $\mathrm{N}=1685, \mathrm{M}=6.5, \mathrm{SD}=7.3$ & $1.01(0.94$ to 1.09$)$ & 0.70 \\
18 to 20 October 2021 (wave 60) & $\mathrm{N}=1590, \mathrm{M}=6.3, \mathrm{SD}=7.1$ & $0.98(0.91$ to 1.06$)$ & 0.61 \\
1 to 4 November 2021 (wave 61) & $\mathrm{N}=1833, \mathrm{M}=6.4, \mathrm{SD}=7.5$ & $1.01(0.94$ to 1.08$)$ & 0.83 \\
15 to 17 November 2021 (wave & $\mathrm{N}=1864, \mathrm{M}=7.1, \mathrm{SD}=8.9$ & $1.10(1.02$ to 1.19$)$ & 0.01 \\
62) & & & \\
29 November to 1 December & $\mathrm{N}=1743, \mathrm{M}=6.2, \mathrm{SD}=7.5$ & $0.98(0.91$ to 1.06$)$ & 0.63 \\
2021 (wave 63) & & & \\
6 to 8 December 2021 (wave & $\mathrm{N}=1679, \mathrm{M}=6.6, \mathrm{SD}=7.4$ & $1.03(0.96$ to 1.11$)$ & 0.36 \\
63.5) & & & \\
13 to 16 December 2021 (wave & $\mathrm{N}=1841, \mathrm{M}=6.4, \mathrm{SD}=7.3$ & $0.99(0.92$ to 1.07$)$ & 0.84 \\
64) & $\mathrm{N}=1876, \mathrm{M}=5.8, \mathrm{SD}=6.6$ & $0.90(0.84$ to 0.96) & 0.003 \\
4 to 6 January 2022 (wave 65) & $\mathrm{R}$ & & Reference \\
\hline 17 to 20 January 2022 (wave 66) & $\mathrm{N}=1913, \mathrm{M}=6.4, \mathrm{SD}=7.4$ & & \\
\hline
\end{tabular}


Table 7. Associations between total outings for shopping, to see people from another household, to go to a restaurant/café/pub, and go out to work (in those who reported working) and survey wave, between July 2020 and May 2021.

\begin{tabular}{|c|c|c|c|}
\hline Survey wave & $\begin{array}{l}\text { Number of responses, mean number } \\
\text { of outings, SD [total } n=25,097 \text { ] }\end{array}$ & $\begin{array}{l}\text { Incidence rate ratio } \\
(95 \% \mathrm{CI})\end{array}$ & p-value \\
\hline Overall & - & $\chi^{2}(26)=572.2$ & $<0.001$ \\
\hline 6 to 8 July 2020 (wave 24 ) & $\mathrm{N}=950, \mathrm{M}=5.8, \mathrm{SD}=6.8$ & Reference & Reference \\
\hline 20 to 22 July 2020 (wave 25 ) & $\mathrm{N}=960, \mathrm{M}=6.6, \mathrm{SD}=6.3$ & $1.16(1.07$ to 1.27$)$ & 0.001 \\
\hline 3 to 5 August 2020 (wave 26) & $\mathrm{N}=908, \mathrm{M}=7.0, \mathrm{SD}=7.4$ & $1.23(1.12$ to 1.36$)$ & $<0.001$ \\
\hline 1 to 2 September 2020 (wave 27 ) & $\mathrm{N}=959, \mathrm{M}=7.8, \mathrm{SD}=7.0$ & $1.37(1.25$ to 1.5$)$ & $<0.001$ \\
\hline $\begin{array}{l}14 \text { to } 16 \text { September } 2020 \text { (wave } \\
\text { 28) }\end{array}$ & $\mathrm{N}=940, \mathrm{M}=7.5, \mathrm{SD}=6.7$ & $1.32(1.20$ to 1.44$)$ & $<0.001$ \\
\hline $\begin{array}{l}28 \text { to } 30 \text { September } 2020 \text { (wave } \\
\text { 29) }\end{array}$ & $\mathrm{N}=940, \mathrm{M}=7.3, \mathrm{SD}=6.7$ & $1.28(1.17$ to 1.40$)$ & $<0.001$ \\
\hline 12 to 14 October 2020 (wave 30 ) & $\mathrm{N}=918, \mathrm{M}=7.6, \mathrm{SD}=6.6$ & $1.32(1.21$ to 1.44$)$ & $<0.001$ \\
\hline 26 to 28 October 2020 (wave 31 ) & $\mathrm{N}=868, \mathrm{M}=7.0, \mathrm{SD}=6.1$ & $1.22(1.12$ to 1.34$)$ & $<0.001$ \\
\hline 9 to 11 November 2020 (wave 32) & $\mathrm{N}=928, \mathrm{M}=6.5, \mathrm{SD}=7.6$ & $1.14(1.03$ to 1.26$)$ & 0.01 \\
\hline $\begin{array}{l}16 \text { to } 18 \text { November } 2020 \text { (wave } \\
33 \text { ) }\end{array}$ & $\mathrm{N}=966, \mathrm{M}=6.2, \mathrm{SD}=7.9$ & $1.08(0.97$ to 1.21$)$ & 0.14 \\
\hline $\begin{array}{l}23 \text { to } 25 \text { November } 2020 \text { (wave } \\
34 \text { ) }\end{array}$ & $\mathrm{N}=936, \mathrm{M}=5.9, \mathrm{SD}=6.2$ & $1.03(0.94$ to 1.14$)$ & 0.50 \\
\hline $\begin{array}{l}30 \text { November to } 2 \text { December } \\
2020 \text { (wave } 35 \text { ) }\end{array}$ & $\mathrm{N}=967, \mathrm{M}=6.3, \mathrm{SD}=7.7$ & $1.12(1.01$ to 1.24$)$ & 0.03 \\
\hline 7 to 9 December 2020 (wave 36) & $\mathrm{N}=977, \mathrm{M}=6.4, \mathrm{SD}=6.2$ & 1.12 (1.02 to 1.22$)$ & 0.02 \\
\hline $\begin{array}{l}14 \text { to } 16 \text { December } 2020 \text { (wave } \\
\text { 37) }\end{array}$ & $\mathrm{N}=914, \mathrm{M}=6.3, \mathrm{SD}=5.5$ & $1.11(1.02$ to 1.21$)$ & 0.02 \\
\hline $\begin{array}{l}21 \text { to } 23 \text { December } 2020 \text { (wave } \\
38 \text { ) }\end{array}$ & $\mathrm{N}=907, \mathrm{M}=6.2, \mathrm{SD}=6.5$ & $1.09(0.99$ to 1.20$)$ & 0.10 \\
\hline $\begin{array}{l}28 \text { to } 30 \text { December } 2020 \text { (wave } \\
\text { 39) }\end{array}$ & $\mathrm{N}=990, \mathrm{M}=5.5, \mathrm{SD}=6.5$ & $0.96(0.87$ to 1.06$)$ & 0.46 \\
\hline 4 to 6 January 2021 (wave 40 ) & $\mathrm{N}=911, \mathrm{M}=4.9, \mathrm{SD}=6.1$ & $0.86(0.78$ to 0.96$)$ & 0.005 \\
\hline 11 to 13 January 2021 (wave 41 ) & $\mathrm{N}=950, \mathrm{M}=4.5, \mathrm{SD}=5.0$ & $0.79(0.71$ to 0.87$)$ & $<0.001$ \\
\hline 25 to 27 January 2021 (wave 42 ) & $\mathrm{N}=945, \mathrm{M}=4.8, \mathrm{SD}=5.5$ & $0.84(0.76$ to 0.93$)$ & 0.001 \\
\hline 8 to 10 February 2021 (wave 43 ) & $\mathrm{N}=912, \mathrm{M}=5.2, \mathrm{SD}=5.6$ & $0.90(0.82$ to 1.00$)$ & 0.04 \\
\hline 22 to 24 February 2021 (wave 44 ) & $\mathrm{N}=904, \mathrm{M}=5.8, \mathrm{SD}=7.2$ & $1.02(0.92$ to 1.13$)$ & 0.73 \\
\hline 8 to 10 March 2021 (wave 45 ) & $\mathrm{N}=908, \mathrm{M}=5.8, \mathrm{SD}=7.0$ & $1.02(0.92$ to 1.13$)$ & 0.74 \\
\hline 22 to 24 March 2021 (wave 46 ) & $\mathrm{N}=879, \mathrm{M}=6.4, \mathrm{SD}=6.7$ & $1.10(1.00$ to 1.22$)$ & 0.05 \\
\hline 5 to 7 April 2021 (wave 47) & $\mathrm{N}=915, \mathrm{M}=6.7, \mathrm{SD}=6.6$ & $1.15(1.05$ to 1.27$)$ & 0.003 \\
\hline 19 to 21 April 2021 (wave 48 ) & $\mathrm{N}=928, \mathrm{M}=7.3, \mathrm{SD}=7.1$ & $1.28(1.17$ to 1.41$)$ & $<0.001$ \\
\hline 4 to 5 May 2021 (wave 49) & $\mathrm{N}=939, \mathrm{M}=7.5, \mathrm{SD}=6.1$ & $1.31(1.20$ to 1.42$)$ & $<0.001$ \\
\hline 17 to 19 May 2021 (wave 50) & $\mathrm{N}=878, \mathrm{M}=7.6, \mathrm{SD}=6.6$ & $1.33(1.22$ to 1.46$)$ & $<0.001$ \\
\hline
\end{tabular}


Table 8. Associations between total outings for shopping, to see people from another household, to go to a restaurant/café/pub, and go out to work (in those who reported working) and survey wave, between June 2021 and January 2022.

\begin{tabular}{|c|c|c|c|}
\hline Survey wave & $\begin{array}{l}\text { Number of responses, mean number } \\
\text { of outings, SD [total } n=16,087]\end{array}$ & $\begin{array}{l}\text { Incidence rate ratio } \\
(95 \% \mathrm{CI})\end{array}$ & p-value \\
\hline Overall & - & $\chi^{2}(16)=135.3$ & $<0.001$ \\
\hline 1 to 2 June 2021 (wave 51 ) & $\mathrm{N}=955, \mathrm{M}=8.3, \mathrm{SD}=5.7$ & Reference & Reference \\
\hline 14 to 16 June 2021 (wave 52 ) & $\mathrm{N}=869, \mathrm{M}=8.7, \mathrm{SD}=6.3$ & $1.04(0.98$ to 1.11$)$ & 0.18 \\
\hline 28 to 29 June 2021 (wave 53) & $\mathrm{N}=985, \mathrm{M}=8.4, \mathrm{SD}=6.0$ & $1.01(0.95$ to 1.07$)$ & 0.76 \\
\hline 26 to 27 July 2021 (wave 54) & $\mathrm{N}=954, \mathrm{M}=8.8, \mathrm{SD}=6.4$ & 1.05 (0.99 to 1.12$)$ & 0.10 \\
\hline 9 to 10 August 2021 (wave 55) & $\mathrm{N}=922, \mathrm{M}=8.8, \mathrm{SD}=6.2$ & $1.06(0.99$ to 1.13$)$ & 0.08 \\
\hline 23 to 24 August 2021 (wave 56) & $\mathrm{N}=942, \mathrm{M}=8.9, \mathrm{SD}=6.1$ & $1.07(1.01$ to 1.14$)$ & 0.02 \\
\hline 6 to 7 September 2021 (wave 57) & $\mathrm{N}=961, \mathrm{M}=8.3, \mathrm{SD}=5.8$ & $1.00(0.94$ to 1.07$)$ & 0.92 \\
\hline $\begin{array}{l}20 \text { to } 22 \text { September } 2021 \text { (wave } \\
58 \text { ) }\end{array}$ & $\mathrm{N}=849, \mathrm{M}=9.7, \mathrm{SD}=9.1$ & $1.20(1.11$ to 1.29$)$ & $<0.001$ \\
\hline 4 to 6 October 2021 (wave 59) & $\mathrm{N}=888, \mathrm{M}=9.7, \mathrm{SD}=8.6$ & $1.17(1.09$ to 1.26$)$ & $<0.001$ \\
\hline 18 to 20 October 2021 (wave 60 ) & $\mathrm{N}=802, \mathrm{M}=9.6, \mathrm{SD}=8.0$ & $1.16(1.08$ to 1.24$)$ & $<0.001$ \\
\hline 1 to 4 November 2021 (wave 61 ) & $\mathrm{N}=959, \mathrm{M}=9.8, \mathrm{SD}=9.4$ & $1.20(1.11$ to 1.29$)$ & $<0.001$ \\
\hline $\begin{array}{l}15 \text { to } 17 \text { November } 2021 \text { (wave } \\
62 \text { ) }\end{array}$ & $\mathrm{N}=1031, \mathrm{M}=10.4, \mathrm{SD}=10.5$ & $1.25(1.16$ to 1.35$)$ & $<0.001$ \\
\hline $\begin{array}{l}29 \text { November to } 1 \text { December } \\
2021 \text { (wave 63) }\end{array}$ & $\mathrm{N}=943, \mathrm{M}=9.6, \mathrm{SD}=9.4$ & $1.16(1.08$ to 1.25$)$ & $<0.001$ \\
\hline $\begin{array}{l}6 \text { to } 8 \text { December } 2021 \text { (wave } \\
63.5 \text { ) }\end{array}$ & $\mathrm{N}=949, \mathrm{M}=10.0, \mathrm{SD}=8.9$ & $1.21(1.13$ to 1.30$)$ & $<0.001$ \\
\hline $\begin{array}{l}13 \text { to } 16 \text { December } 2021 \text { (wave } \\
64 \text { ) }\end{array}$ & $\mathrm{N}=1005, \mathrm{M}=9.4, \mathrm{SD}=8.3$ & $1.14(1.06$ to 1.22$)$ & $<0.001$ \\
\hline 4 to 6 January 2022 (wave 65 ) & $\mathrm{N}=1008, \mathrm{M}=8.2, \mathrm{SD}=8.2$ & $0.98(0.91$ to 1.05$)$ & 0.52 \\
\hline 17 to 20 January 2022 (wave 66 ) & $\mathrm{N}=1065, \mathrm{M}=9.8, \mathrm{SD}=9.0$ & $1.19(1.11$ to 1.27$)$ & $<0.001$ \\
\hline
\end{tabular}


Table 9. Associations between total outings and national lockdown.

\begin{tabular}{|c|c|c|c|}
\hline \multicolumn{4}{|c|}{ Total outings for shopping and to see people from another household } \\
\hline Lockdown & $\begin{array}{l}\text { Number of responses, mean number } \\
\text { of outings, SD [total } n=20,733 \text { ] }\end{array}$ & $\begin{array}{l}\text { Incidence rate ratio } \\
(95 \% \mathrm{CI})\end{array}$ & p-value \\
\hline Overall & - & $\chi^{2}(2)=574.4$ & $<0.001$ \\
\hline $\begin{array}{l}\text { First lockdown ( } 30 \text { March to } 6 \\
\text { May 2020, waves } 10 \text { to } 15)\end{array}$ & $\mathrm{N}=10,376, \mathrm{M}=2.0, \mathrm{SD}=3.0$ & Reference & Reference \\
\hline $\begin{array}{l}\text { Second lockdown (16 November } \\
\text { to } 2 \text { December } 2020 \text {, waves } 33 \text { to } \\
35 \text { ) }\end{array}$ & $\mathrm{N}=5289, \mathrm{M}=3.4, \mathrm{SD}=4.7$ & $1.67(1.60$ to 1.75$)$ & $<0.001$ \\
\hline $\begin{array}{l}\text { Third lockdown ( } 25 \text { January to } \\
\text { February } 2021 \text {, waves } 42 \text { to } 44 \text { ) }\end{array}$ & $\mathrm{N}=5068, \mathrm{M}=3.0, \mathrm{SD}=4.5$ & $1.47(1.40$ to 1.55$)$ & $<0.001$ \\
\hline \multicolumn{4}{|c|}{ Total outings for shopping, to see people from another household, and to go to a restaurant/café/pub } \\
\hline Lockdown & $\begin{array}{l}\text { Number of responses, mean number } \\
\text { of outings, SD [total } n=10,357 \text { ] }\end{array}$ & $\begin{array}{l}\text { Incidence rate ratio } \\
(95 \% \mathrm{CI})\end{array}$ & p-value \\
\hline $\begin{array}{l}\text { Second lockdown (16 November } \\
\text { to } 2 \text { December } 2020 \text {, waves } 33 \text { to } \\
35)\end{array}$ & $\mathrm{N}=5289, \mathrm{M}=3.7, \mathrm{SD}=5.5$ & Reference & Reference \\
\hline $\begin{array}{l}\text { Third lockdown ( } 25 \text { January to } \\
\text { February } 2021 \text {, waves } 42 \text { to } 44 \text { ) }\end{array}$ & $\mathrm{N}=5068, \mathrm{M}=3.2, \mathrm{SD}=4.9$ & $0.87(0.82$ to 0.92$)$ & $<0.001$ \\
\hline \multicolumn{4}{|c|}{$\begin{array}{l}\text { Total outings for shopping, to see people from another household, to go to a restaurant/café/pub, and go out } \\
\text { to work (in those who reported working) }\end{array}$} \\
\hline Lockdown & $\begin{array}{l}\text { Number of responses, mean number } \\
\text { of outings, SD [total } n=5,630 \text { ] }\end{array}$ & $\begin{array}{l}\text { Incidence rate ratio } \\
(95 \% \mathrm{CI})\end{array}$ & p-value \\
\hline $\begin{array}{l}\text { Second lockdown (16 November } \\
\text { to } 2 \text { December } 2020 \text {, waves } 33 \text { to } \\
35)\end{array}$ & $\mathrm{N}=2869, \mathrm{M}=6.1, \mathrm{SD}=7.3$ & Reference & Reference \\
\hline $\begin{array}{l}\text { Third lockdown ( } 25 \text { January to } \\
\text { February } 2021 \text {, waves } 42 \text { to } 44 \text { ) }\end{array}$ & $\mathrm{N}=2761, \mathrm{M}=5.3, \mathrm{SD}=6.1$ & $0.86(0.81$ to 0.91$)$ & $<0.001$ \\
\hline
\end{tabular}


Table 10. Associations between frequent wearing of a face covering and survey wave, between April 2020 and May 2021.

\begin{tabular}{|c|c|c|c|c|}
\hline Survey wave & $\begin{array}{l}\text { Infrequent } \\
\text { hand washing } \\
\text { [total } \\
\mathrm{n}=17,041], \mathrm{n} \\
(\%)\end{array}$ & $\begin{array}{l}\text { Frequent hand } \\
\text { washing } \\
{[\mathrm{n}=35,196], \mathrm{n}} \\
(\%)\end{array}$ & Odds ratio $(95 \% \mathrm{CI})$ & p-value \\
\hline Overall & - & - & $\chi^{2}(36)=8118.2$ & $<0.001$ \\
\hline 27 to 29 April 2020 (wave 14 ) & $1075(85.0)$ & $189(15.0)$ & Reference & Reference \\
\hline 4 to 6 May 2020 (wave 15 ) & $1084(85.8)$ & $179(14.2)$ & $0.98(0.79$ to 1.22$)$ & 0.88 \\
\hline 11 to 13 May 2020 (wave 16 ) & $1096(84.8)$ & $197(15.2)$ & 1.07 (0.87 to 1.32$)$ & 0.52 \\
\hline 18 to 20 May 2020 (wave 17 ) & $810(61.3)$ & $511(38.7)$ & $3.74(3.11$ to 4.50$)$ & $<0.001$ \\
\hline 26 to 27 May 2020 (wave 18 ) & $835(62.4)$ & $503(37.6)$ & $3.58(2.97$ to 4.30$)$ & $<0.001$ \\
\hline 1 to 3 June 2020 (wave 19 ) & $840(62.7)$ & $500(37.3)$ & $3.48(2.90$ to 4.19$)$ & $<0.001$ \\
\hline 8 to 10 June 2020 (wave 20 ) & $790(59.4)$ & $539(40.6)$ & $4.03(3.35$ to 4.84$)$ & $<0.001$ \\
\hline 15 to 17 June 2020 (wave 21 ) & $795(57.9)$ & $577(42.1)$ & $4.30(3.58$ to 5.16$)$ & $<0.001$ \\
\hline 22 to 24 June 2020 (wave 22 ) & $764(56.1)$ & $599(43.9)$ & $4.67(3.89$ to 5.60$)$ & $<0.001$ \\
\hline 29 June to 1 July 2020 (wave 23 ) & $754(54.9)$ & $619(45.1)$ & $4.90(4.09$ to 5.88$)$ & $<0.001$ \\
\hline 6 to 8 July 2020 (wave 24 ) & $710(51.4)$ & $670(48.6)$ & $5.59(4.66$ to 6.71$)$ & $<0.001$ \\
\hline 20 to 22 July 2020 (wave 25 ) & $610(42.7)$ & $820(57.3)$ & $8.01(6.68$ to 9.61$)$ & $<0.001$ \\
\hline 3 to 5 August 2020 (wave 26) & $335(23.4)$ & $1095(76.6)$ & $19.42(16.00$ to 23.57$)$ & $<0.001$ \\
\hline 1 to 2 September 2020 (wave 27) & $307(20.8)$ & $1171(79.2)$ & $22.90(18.82$ to 27.86$)$ & $<0.001$ \\
\hline 14 to 16 September 2020 (wave 28 ) & $291(19.5)$ & $1202(80.5)$ & $24.48(20.08$ to 29.85$)$ & $<0.001$ \\
\hline 28 to 30 September 2020 (wave 29) & $281(18.9)$ & $1207(81.1)$ & $25.46(20.87$ to 31.06$)$ & $<0.001$ \\
\hline 12 to 14 October 2020 (wave 30 ) & $252(16.1)$ & $1313(83.9)$ & $30.96(25.28$ to 37.91$)$ & $<0.001$ \\
\hline 26 to 28 October 2020 (wave 31 ) & $258(17.5)$ & $1220(82.5)$ & $27.93(22.84$ to 34.15$)$ & $<0.001$ \\
\hline 9 to 11 November 2020 (wave 32) & $266(19.0)$ & $1134(81.0)$ & $25.57(20.89$ to 31.29$)$ & $<0.001$ \\
\hline 16 to 18 November 2020 (wave 33 ) & $290(19.8)$ & $1177(80.2)$ & $24.46(20.08$ to 29.79$)$ & $<0.001$ \\
\hline 23 to 25 November 2020 (wave 34 ) & $276(18.9)$ & $1182(81.1)$ & $25.55(20.95$ to 31.16$)$ & $<0.001$ \\
\hline $\begin{array}{l}30 \text { November to } 2 \text { December } 2020 \\
\text { (wave } 35 \text { ) }\end{array}$ & $270(17.6)$ & $1262(82.4)$ & $27.75(22.75$ to 33.86$)$ & $<0.001$ \\
\hline 7 to 9 December 2020 (wave 36) & $277(18.3)$ & $1237(81.7)$ & $26.52(21.73$ to 32.37$)$ & $<0.001$ \\
\hline 14 to 16 December 2020 (wave 37) & $237(16.6)$ & $1194(83.4)$ & $30.27(24.65$ to 37.17$)$ & $<0.001$ \\
\hline 21 to 23 December 2020 (wave 38 ) & $250(17.4)$ & $1185(82.6)$ & $27.94(22.82$ to 34.21$)$ & $<0.001$ \\
\hline 28 to 30 December 2020 (wave 39) & $258(18.1)$ & $1166(81.9)$ & $26.79(21.90$ to 32.76$)$ & $<0.001$ \\
\hline 4 to 6 January 2021 (wave 40) & $199(14.0)$ & $1219(86.0)$ & $36.51(29.55$ to 45.11$)$ & $<0.001$ \\
\hline 11 to 13 January 2021 (wave 41 ) & $255(18.6)$ & $1116(81.4)$ & $25.95(21.17$ to 31.80$)$ & $<0.001$ \\
\hline 25 to 27 January 2021 (wave 42 ) & $262(19.5)$ & $1083(80.5)$ & $24.68(20.17$ to 30.20$)$ & $<0.001$ \\
\hline 8 to 10 February 2021 (wave 43 ) & $245(17.9)$ & $1127(82.1)$ & $27.39(22.34$ to 33.58$)$ & $<0.001$ \\
\hline 22 to 24 February 2021 (wave 44) & $236(17.1)$ & $1146(82.9)$ & $28.73(23.39$ to 35.28$)$ & $<0.001$ \\
\hline 8 to 10 March 2021 (wave 45) & $285(19.7)$ & $1164(80.3)$ & 24.41 (20.01 to 29.77$)$ & $<0.001$ \\
\hline 22 to 24 March 2021 (wave 46 ) & $290(19.7)$ & $1179(80.3)$ & $24.10(19.79$ to 29.35$)$ & $<0.001$ \\
\hline 5 to 7 April 2021 (wave 47) & $326(22.5)$ & $1125(77.5)$ & $20.53(16.92$ to 24.92$)$ & $<0.001$ \\
\hline 19 to 21 April 2021 (wave 48 ) & $319(22.2)$ & $1117(77.8)$ & $20.75(17.08$ to 25.20$)$ & $<0.001$ \\
\hline 4 to 5 May 2021 (wave 49) & $300(21.0)$ & $1126(79.0)$ & $22.09(18.14$ to 26.90$)$ & $<0.001$ \\
\hline 17 to 19 May 2021 (wave 50) & $313(21.5)$ & $1146(78.5)$ & $21.71(17.87$ to 26.38$)$ & $<0.001$ \\
\hline
\end{tabular}


Table 11. Associations between frequent wearing of a face covering and survey wave, between October 2020 and May 2021.

\begin{tabular}{|c|c|c|c|c|}
\hline Survey wave & $\begin{array}{l}\text { Infrequent } \\
\text { wearing of face } \\
\text { covering [total } \\
\mathrm{n}=5,412], \mathrm{n}(\%)\end{array}$ & $\begin{array}{l}\text { Frequent } \\
\text { wearing of face } \\
\text { covering [total } \\
\mathrm{n}=23,305], \mathrm{n} \\
(\%)\end{array}$ & Odds ratio $(95 \% \mathrm{CI})$ & p-value \\
\hline Overall & - & - & $\chi^{2}(19)=82.3$ & $<0.001$ \\
\hline 26 to 28 October 2020 (wave 31 ) & $258(17.5)$ & $1220(82.5)$ & Reference & Reference \\
\hline 9 to 11 November 2020 (wave 32) & $266(19.0)$ & $1134(81.0)$ & $0.95(0.79$ to 1.14$)$ & 0.58 \\
\hline $\begin{array}{l}16 \text { to } 18 \text { November } 2020 \text { (wave } \\
33 \text { ) }\end{array}$ & $290(19.8)$ & $1177(80.2)$ & $0.91(0.76$ to 1.09$)$ & 0.32 \\
\hline $\begin{array}{l}23 \text { to } 25 \text { November } 2020 \text { (wave } \\
34 \text { ) }\end{array}$ & $276(18.9)$ & $1182(81.1)$ & $0.94(0.79$ to 1.13$)$ & 0.52 \\
\hline $\begin{array}{l}30 \text { November to } 2 \text { December } \\
2020 \text { (wave } 35 \text { ) }\end{array}$ & $270(17.6)$ & $1262(82.4)$ & $1.02(0.85$ to 1.22$)$ & 0.83 \\
\hline 7 to 9 December 2020 (wave 36) & $277(18.3)$ & $1237(81.7)$ & $0.98(0.82$ to 1.16$)$ & 0.78 \\
\hline $\begin{array}{l}14 \text { to } 16 \text { December } 2020 \text { (wave } \\
37 \text { ) }\end{array}$ & $237(16.6)$ & $1194(83.4)$ & $1.13(0.94$ to 1.36$)$ & 0.21 \\
\hline $\begin{array}{l}21 \text { to } 23 \text { December } 2020 \text { (wave } \\
38 \text { ) }\end{array}$ & $250(17.4)$ & $1185(82.6)$ & $1.03(0.86$ to 1.23$)$ & 0.77 \\
\hline $\begin{array}{l}28 \text { to } 30 \text { December } 2020 \text { (wave } \\
\text { 39) }\end{array}$ & $258(18.1)$ & $1166(81.9)$ & $0.98(0.82$ to 1.18$)$ & 0.86 \\
\hline 4 to 6 January 2021 (wave 40 ) & $199(14.0)$ & $1219(86.0)$ & $1.33(1.10$ to 1.61$)$ & 0.003 \\
\hline 11 to 13 January 2021 (wave 41 ) & $255(18.6)$ & $1116(81.4)$ & $0.95(0.79$ to 1.14$)$ & 0.57 \\
\hline 25 to 27 January 2021 (wave 42 ) & $262(19.5)$ & $1083(80.5)$ & $0.92(0.76$ to 1.10$)$ & 0.35 \\
\hline 8 to 10 February 2021 (wave 43 ) & $245(17.9)$ & $1127(82.1)$ & $1.00(0.83$ to 1.20$)$ & 0.99 \\
\hline 22 to 24 February 2021 (wave 44 ) & $236(17.1)$ & $1146(82.9)$ & $1.04(0.86$ to 1.25$)$ & 0.67 \\
\hline 8 to 10 March 2021 (wave 45) & $285(19.7)$ & $1164(80.3)$ & $0.90(0.75$ to 1.07$)$ & 0.22 \\
\hline 22 to 24 March 2021 (wave 46) & $290(19.7)$ & $1179(80.3)$ & $0.88(0.73$ to 1.04$)$ & 0.14 \\
\hline 5 to 7 April 2021 (wave 47) & $326(22.5)$ & $1125(77.5)$ & $0.75(0.63$ to 0.89$)$ & 0.001 \\
\hline 19 to 21 April 2021 (wave 48 ) & $319(22.2)$ & $1117(77.8)$ & $0.76(0.64$ to 0.90$)$ & 0.002 \\
\hline 4 to 5 May 2021 (wave 49) & $300(21.0)$ & $1126(79.0)$ & $0.83(0.69$ to 0.99$)$ & 0.04 \\
\hline 17 to 19 May 2021 (wave 50) & $313(21.5)$ & $1146(78.5)$ & $0.79(0.67$ to 0.95$)$ & 0.009 \\
\hline
\end{tabular}

This analysis was run using an exchangeable correlation matrix. 